\title{
The origins of Early Lapita culture: the testimony of historical linguistics
}

\author{
Andrew Pawley \\ Department of Linguistics \\ Research School of Pacific and Asian Studies \\ The Australian National University \\ Canberra, ACT, 0200, Australia \\ andrew.pawley@anu.edu.au
}

\section{Introduction}

Debate on the nature and origins of the culture known as Early (Western) Lapita has been clouded by the limited range of the available archaeological evidence defining this culture ${ }^{1}$. Although 50 years of archaeological research in the southwest Pacific have yielded more than 200 sites distributed from the Bismarck Archipelago to western Polynesia where Lapita pottery has been found (see Bedford and Sand this volume), and archaeologists have gained a detailed understanding of regional and temporal variations in decorative styles and vessel forms, sampling problems have prevented them from recovering anything like the full range of material culture associated with Lapita communities.

One kind of sampling problem has to do with the scale of excavations. Few Lapita habitation sites have been excavated on the large scale needed to recover a fully representative range of materials - artefacts, settlement patterns, faunal remains, etc. This sort of sampling deficiency is likely to be ameliorated by further research. But there is a second kind of shortfall that cannot be remedied because it is in the nature of archaeological assemblages. In Neolithic societies a very high proportion of artefacts are made of perishable materials. This means that even the most artefact-rich assemblages will contain only a small fraction of the total range of artefact types. Kirch and Green (2001:164ff) examined ethnographic records of artefacts for a sample of five traditional Polynesian material cultures and found that, on average, only around 18 percent of artefact types were durable (the range was 14-23\%). And when it comes to drawing inferences from nonmaterial culture, archaeologists generally have even less material to work with. These sampling problems, of 
course, apply not only to Lapita sites but to the cultural traditions that preceded Lapita in the archaeological record for the Bismarck Archipelago and Island Southeast Asia.

This paper will focus on two questions: ${ }^{2}$

1. What can lexical evidence from historical linguistics add to the accounts of Early Lapita culture provided by archaeology?

2. What can lexical evidence tell us about the antecedents of Early Lapita culture in the Neolithic cultures of Island South Asia?

A third question will also be briefly addressed:

3. Can comparative linguistics tell us anything about the interaction between speakers of Austronesian and non-Austronesian languages in the Lapita period?

Historical linguistics can, under certain circumstances, provide evidence that supplements the archaeological record. The lexicon of a language (its store of words and fixed multiword expressions) is a body of intangible artefacts that tells much about the way of life of the speech community. By tracing the histories of words, but more especially tight-knit terminologies, sets of words representing particular semantic fields, we can learn a great deal about continuities and changes in the way of life of the people who used these words.

However, anyone seeking to marry a (reconstructed) linguistic prehistory with a (reconstructed) archaeological prehistory faces a number of methodological challenges. The most fundamental one is to match particular archaeological assemblages with particular languages. In many regions of the world, this sort of matching has proved impossible to achieve with any degree of confidence. It happens that in Pacific prehistory we have a rare piece of good fortune: there is a well-attested archaeological horizon, namely Lapita, that can be securely correlated with a well-established linguistic dispersal, namely, that of the Oceanic languages. In particular, the bearers of the Early Lapita culture who occupied parts of the Bismarck Archipelago around $3300 \mathrm{BP}$ can be equated with the speech community that spoke Proto Oceanic, the Austronesian interstage that was the immediate ancestor of all the Oceanic languages.

The argument will be that if it can be shown that Proto Oceanic speakers retained a named concept from an earlier stage, Proto Malayo-Polynesian, generally regarded as having been spoken in the Philippines (see below), then (by definition) that concept was part of the cultural apparatus they brought with them into the Bismarcks. I will present evidence from terminologies belonging to 11 cultural domains, most of which concern material culture. The domains are 1. canoes and sailing, 2. houses and settlement patterns, 3. fishing methods and technology, 4. agriculture and arboriculture, 5. domestic animals, 6. pottery, 7. cooking, 8. cutting implements, 9. clothing, weaving, ornaments and decoration, 10. kinship, and 11. leadership and other social categories.

\section{How Southeast Asian is Lapita? The debate about Lapita origins}

In the 1970s a case was built up that Lapita pottery forms were simply the most visible part of a culture complex whose distinctive elements were fairly homogeneous throughout the geographic range of Lapita habitation sites (Bellwood 1978; Golson 1971; Green 1979). A number of scholars argued that the spread of the Oceanic branch of Austronesian languages across the southwest Pacific was associated with Lapita and with other Neolithic cultures of Island Melanesia which were roughly contemporaneous with, or in some cases, possibly even earlier than Lapita, and that all were ultimately derived from Island Southeast Asia (Bellwood 1978; Pawley and Green 1973; Shutler and Marck 1975).

Lapita was seen as being a culture quite different from any which preceded it in the record for Melanesia. Its most prominent markers are earthenware vessels with red-slipped surfaces, made in a characteristic 
variety of shapes, including large carinated jars and bowls, globular and spherical pots, flat-bottomed dishes and pedestal stands. A minority of vessels were decorated with precise and elaborate geometric motifs, done by dentate stamping, i.e. with repeated applications of a set of toothed implements.

In Lapita sites representing permanent settlements the pottery is part of a cluster of elements artefact types, architecture, settlement patterns and items representing long distance trade. Settlements are in the hamlet to village range and are nearly always situated on small islands or on the coast of large islands and close to beaches that would provide good launching sites and reef passage for canoes. Lapita assemblages contain ground and polished stone and shell adzes; obsidian and chert flake tools, often imported from remote sources; one-piece shell fishhooks; pearlshell knives and scrapers; various kinds of conus shell disks and pendants. Houses were typically rectangular. In some settlements houses were built on stilts over the reef flat. Middens are typically full of lagoon fish and turtle bones, attesting to the importance of fishing and to a variety of fishing techniques. The bones of chicken and pig are sometimes present, indicating that these animals (neither of which was native to Near Oceania) were kept as domesticates.

By 3300-3200 BP Early Lapita communities were established over a wide area of the Bismarcks, including north New Britain, south New Britain, Mussau in the St Matthias group, the Anir group off the southeast coast of New Ireland and (though less well attested in the archaeological record) almost certainly also in the Admiralty Islands. There are several signs that the dispersed communities formed a network of societies, probably related by kinship and marriage, that kept in regular contact at least for two or three centuries. The clearest indicator is the long distance movement between these communities of obsidian from one or both of the only two sources in the region (the Talasea region, on New Britain's Willaumez Peninsula and the Manus group), and also the movement of chert, oven stones and adzes. Another indicator is the parallel changes in pottery styles over the New Britain-Mussau-Anir region over the period 3300-3000 BP (Summerhayes 2000a,b, 2001). By around $3000 \mathrm{BP}$ the intensity of contacts had diminished markedly. In the meantime, by 3200-3100 BP, people carrying Early Lapita had moved beyond the Bismarcks and settled parts of Remote Oceania.

During the 1980s and 1990s, as the archaeological record improved and the history of regional archaeological sequences was clarified, it became evident that the carriers of Lapita were, in fact, the foundation settlers of all those parts of Melanesia that lie in Remote Oceania, as well as of western Polynesia, and that the Lapita dispersal took no more than three or four centuries to reach the Tonga-Samoa area (Burley and Connaughton 2007; Burley et al. 2001; Irwin 1981, 1992; Green 1991a, 1999, 2003; Kirch 1997; Spriggs 1997).

A contrary case for Lapita origins was developed in the latter half of the 1980s and 1990s by a number of scholars associated with the Lapita Homeland Project (Allen and Gosden 1991). This project, beginning in 1985, added greatly to knowledge of the Upper Pleistocene and Early and Mid Holocene archaeological record for the Bismarck Archipelago. Having demonstrated that the Bismarck archipelago has a continuous history of human occupation going back some 30-40,000 years these scholars proposed a predominantly local origin of the Lapita cultures of the Bismarck archipelago (Allen and Gosden 1996; Allen and White 1989; White et al. 1988). They pointed out that the pre-Lapita materials contain precedents for up to 10 elements of Lapita technology and trade patterns, including lagoon fishing, trochus shell armrings, one piece shell fishhooks, earth ovens, and trade in obsidian.

Green (1991a, 1997, 2003) argued against a single source for Lapita. He proposed a "Triple I model", in which some elements of Early Lapita were intrusive, i.e. brought from South East Asia into northwest Melanesia, some were local innovations, developed by Lapita people in Melanesia, and some were of local (Melanesian, presumably non-AN speaking peoples of Melanesia) origin that were integrated into (adopted by) Early Lapita communities.

In broad terms, the Triple I model seems now to be accepted by most specialists. However, "broad" is the operative term. The debate continues over which Early Lapita cultural elements are intrusions, innovations, or borrowings, in the above senses. Kirch $(1995,1997,2000)$ emphasises continuity, observing that "the early 
Lapita assemblages ... fit comfortably within the range of varieties ... for cultural complexes dating to the second and third millennia B.C. in island southeast Asia (1995:2832). Having asked 'How South-East Asian is Lapita?', Spriggs concludes (with Green) that it "is basically of South-East Asian Austronesian origin, with added elements innovated in the Bismarcks, and some integration of pre-Lapita Melanesian elements" (Spriggs 1997:102). As to the balance between these three components, he comments as follows:

Lapita elements of South-East Asian origin would appear to be pottery (or at least particular kinds of pottery), domestic animals, quadrangular adzes, polished stone chisels, various shell ornament types, rectangular houses (some on stilts), large villages, language, and probably aspects of boat technology, tattoo chisels, pearlshell knives, trolling hooks and various stone-artefact classes (Spriggs 1997:101-102). Unique to Melanesia on current evidence were very few elements: some crops, obsidian-stemmed tools and possibly, dorsal-region Tridacna adzes (Spriggs 1997:102).

Spriggs points to a third class of artefacts that are indeterminate between intrusion and integration: items that were present in Melanesia in pre-Lapita times but were also present in early Neolithic assemblages in Island South East Asia. These include "grindstones, hinge-region Tridacna adzes, pierced shell pendants, shell beads, Trochus armbands, one-piece fishhooks, bone points or awls, vegetation clearance by fire, most of the Oceanic domesticated crop complex, shellfishing and reef fishing, earth ovens (at least in Maluku), and some level of long-distance exchange" (Spriggs 1997:102). (He also includes oval/lenticular polished adzes, but there are no pre-Lapita polished stone adzes in Island Melanesia and oval as well as quadrangular adzes are known from Island Southeast Asia (R. Green pers.comm.)).

I turn now to the linguistic evidence bearing on these issues.

\section{The subgrouping and dispersal of Austronesian languages}

Although the outlines of the Austronesian family were discovered in the eighteenth century, it was only in the 1930s that Otto Dempwolff established conclusively that most of the Austronesian languages of the Pacific Islands belong to a single branch of the family. Building on a series of papers he wrote in the 1920s, and on the work of earlier scholars, Dempwolff published a three volume work which provided by far the most systematic reconstruction of the Proto-Austronesian (PAn) sound system (phonology) to date along with more than 2000 reconstructed roots (Dempwolff 1934-38). (Because his sample, crucially, did not include the then little-known Formosan languages Dempwolff's "Proto Austronesian" reconstructions are nowadays equated with "Proto Malayo-Polynesian" (PMP), the largest first-order branch of Austronesian, to be discussed below.)

Dempwolff's sample of some 30 languages from Melanesia showed largely regular correspondences with PMP consonants and vowels. They also showed something even more striking. In vocabulary inherited from PMP, the Austronesian languages of Melanesia shared a sizeable set of common changes to the PMP sound system, changes not present in Austronesian languages west of New Guinea. Furthermore, he observed that the Polynesian languages have undergone the same innovations. This body of shared innovations thus defines a subgroup, nowadays called "Oceanic". Subsequent work has confirmed and extended Dempwolff's main findings in this respect. The innovations of the Oceanic group are shared by all the Austronesian languages of Melanesia east of 138 degrees (from the Sarmi coast of Irian Jaya) but excluding those of Cenderawasih Bay and the Bird's Head of New Guinea, and they are also shared by all the languages of Micronesian except Chamorro and Palauan.

The main phonological innovations attributable to Proto Oceanic (POc) are as follows. (For convenience I refer here to contemporary reconstructions, which make various modifications to Dempwolff's reconstructed sound system and orthography.) In the consonants, there were several mergers (where contrasts between certain pairs of PMP consonants were lost) in POc. PMP ${ }^{*} \mathrm{p}$ and ${ }^{*} \mathrm{~b}$ merged, as did ${ }^{*} \mathrm{k}$ and ${ }^{*} \mathrm{~g}$, ${ }^{*} \mathrm{~d}$ and ${ }^{*} \mathrm{r}$, and ${ }^{*} \mathrm{~s}$ and ${ }^{*} \mathrm{Z}$. 
PMP *h was lost. Several new consonants were added: the labiovelars * ${ }^{*} w,{ }^{*} \mathrm{pw}$, and *mw. In the vowels, PMP *e and *aw merged as *o and * $i$ and *uy merged as *i. The sequence *-ay, which occurred only word-finally, simplified to *-e. There were some other rather complicated developments in the sound system that need not detain us here (for a fuller account see Lynch et al. 2002:63-67). There are also a number of morphological and lexical innovations defining Oceanic.

The proofs of an Oceanic group, now known to contain some 450-500 of the 1000-1200 languages in the Austronesian family, was the first important breakthrough in the high-order subgrouping of Austronesian languages. Subsequent work has shown that Oceanic is no higher than a fourth-order division of Austronesian. The sequence of branchings in the topmost parts of the Austronesian family tree have only become reasonably clear over the past 30 years, mainly due to the work of Robert Blust. Blust has pointed to evidence that supports an initial division of Austronesian into a number of branches represented only in Taiwan and a branch that contains all members of the family spoken outside of Taiwan. This large branch, labelled Malayo-Polynesian (MP), is defined by a number of phonological and morphological innovations (Blust 1977, 1982, 1995b, 1999; Ross 1992, 2005). Blust (1999) now thinks that the Taiwan languages fall into as many as nine different primary subgroups, reinforcing an already strong argument that Taiwan was the Austronesian homeland.

Malayo-Polynesian is in turn classified into (a) a Greater Philippines group (Blust 1991) and an indeterminate number of groups represented in Sulawesi and the Austronesian-speaking areas west of Sulawesi, including Madagascar (Blust and others tend to refer to these groups plus Greater Philippines, collectively, as "Western Malayo-Polynesian"), and (b) a Central-Eastern Malayo-Polynesian (CEMP) branch that contains some 650 languages (Blust 1983-84a, 1993). The dispersal centre of Proto MP was almost certainly the northern Philippines - the Batanes Islands and Luzon - an area settled at around 4000 BP by bearers of a Neolithic culture with close affinities to cultures of south and eastern Taiwan (Bellwood and Dizon 2005).

Proto CEMP was evidently a dialect complex, centred in the Moluccas, that soon broke up into a Central Malayo-Polynesian (CMP) dialect complex and an Eastern Malayo-Polynesian (EMP) branch. CMP comprises chiefly the languages of the Moluccas, the Lesser Sundas east of Sumbawa, and the Austronesian languages of the south side of the Birds Head of New Guinea. EMP divides into the large Oceanic group and a smaller South Halmahera-West New Guinea (SHWNG) group (Blust 1978a). Proto EMP was probably spoken around Cenderawasih Bay, at the neck of the Bird's Head, where the greatest diversity of daughter languages is found.

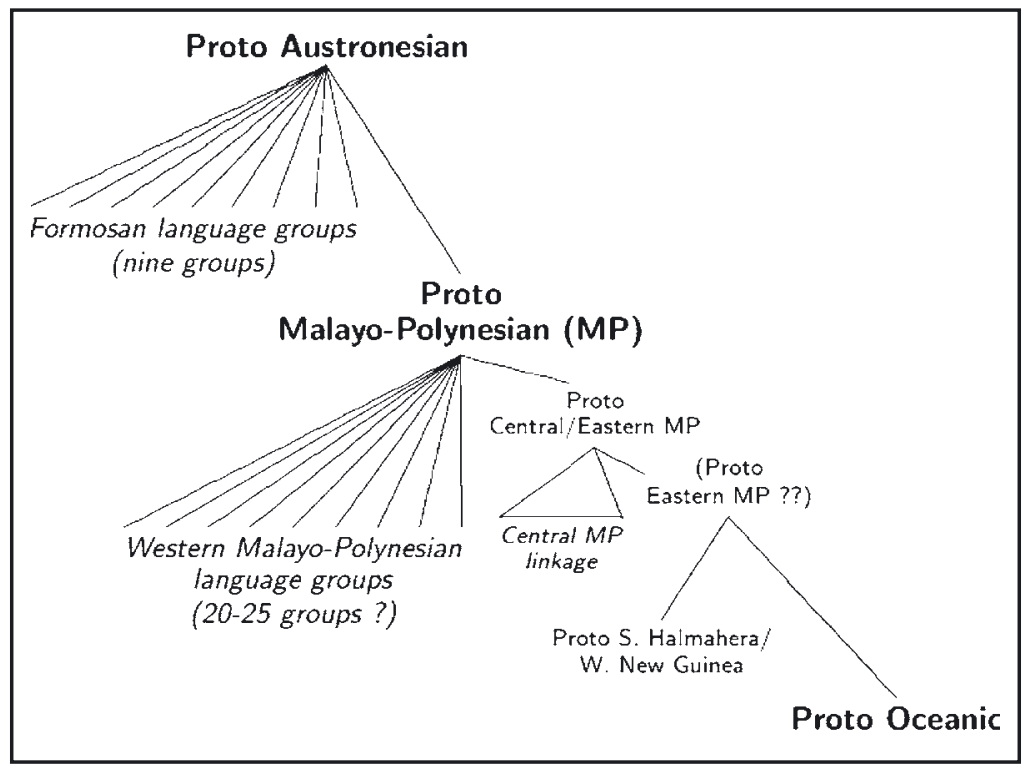

Figure 1. Austronesian family tree: higher order branches. 


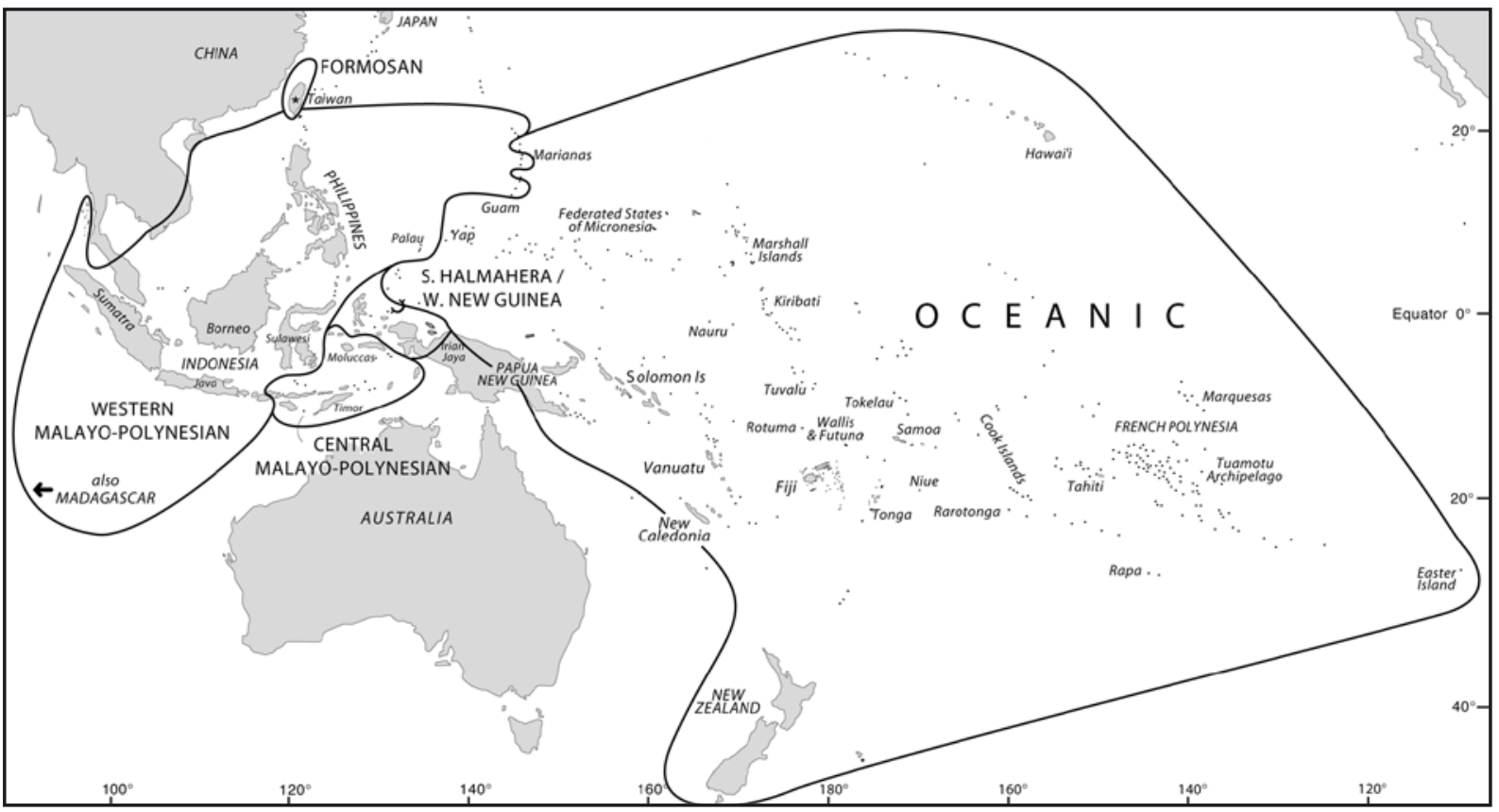

Figure 2. Distribution of the major subgroups of Austronesian.

The Oceanic branch stems from a movement of EMP speakers from the Cenderawasih Bay area of western New Guinea east to the Bismarck Archipelago. The considerable number of innovations defining Oceanic suggests that a significant period of time, probably a few centuries, elapsed between (a) the separation of this branch from the SHWNG subgroup and (b) the breakup of Proto Oceanic (POc).

Given that the closest relatives of Oceanic lie around the neck of the Birds' Head, one might reasonably expect that speakers of pre Oceanic (the phase between Proto SHWNG and Proto Oceanic) at one time lived along the coast of north New Guinea or its offshore islands west of the Bismarcks. But there are no linguistic survivors of such settlements, only tantalising traces in the form of loanwords to Papuan languages of Madang Province (Ross 1988:21). All the Oceanic languages of the north coast of New Guinea are relatively recent "backwash" from the Bismarcks.

The centre of genetic diversity within Oceanic, and the most likely primary dispersal centre for the surviving Oceanic languages, is in the Bismarck Archipelago, where three groups are found that have claims to be first-order subgroups: Admiralties (Blust 1978b, 1996; Ross 1988), Western Oceanic (Ross 1988) and St Matthias (Mussau) (Blust 1984; Ross 1988).

Proto Western Oceanic appears to have been a network of dialects spoken over parts of New Britain, the French Island (Bali-Vitu) and New Ireland (or its offshore eastern islands). It broke up into (a) a Meso-Melanesian dialect complex, initially occupying much the same area as Proto Western Oceanic but later spreading into the northwest Solomons, (b) a North New Guinea dialect complex, extending from the Huon Gulf to Jayapura, and including parts of New Britain, and (c) a Papuan Tip branch, consisting of the Oceanic languages of the Northern Milne Bay and Central Provinces of Papua (Ross 1988).

There is less agreement about the high-order relationships of the Oceanic languages spoken in the eastern half of the main Solomons group and in Remote Oceania. A conservative view is that the following groups may be first-order branches: Southeast Solomonic (Guadalcanal, Gela, Malaita and Makira) (Pawley 1972), Te Motu (the non-Polynesian languages of Te Motu Province, in the eastern Solomons) (Ross and Naess 2007), Yapese (Ross 1996a), Micronesian (Bender 1971; Bender and Wang 1985; Jackson 1983, 1986), NorthCentral Vanuatu, Southern Vanuatu (Lynch 2001), New Caledonia-Loyalties (Haurdricourt 1971), and Central 
Pacific (Fijian, Rotuman and Polynesian) (Geraghty 1983, 1996; Grace 1959; Pawley 1972). However, there is some evidence for linking certain of these groups (reflected in the groupings outlined in Lynch et al. 2002).

Figure 3 gives a conservative view of the more important high-order subgroups of Oceanic.

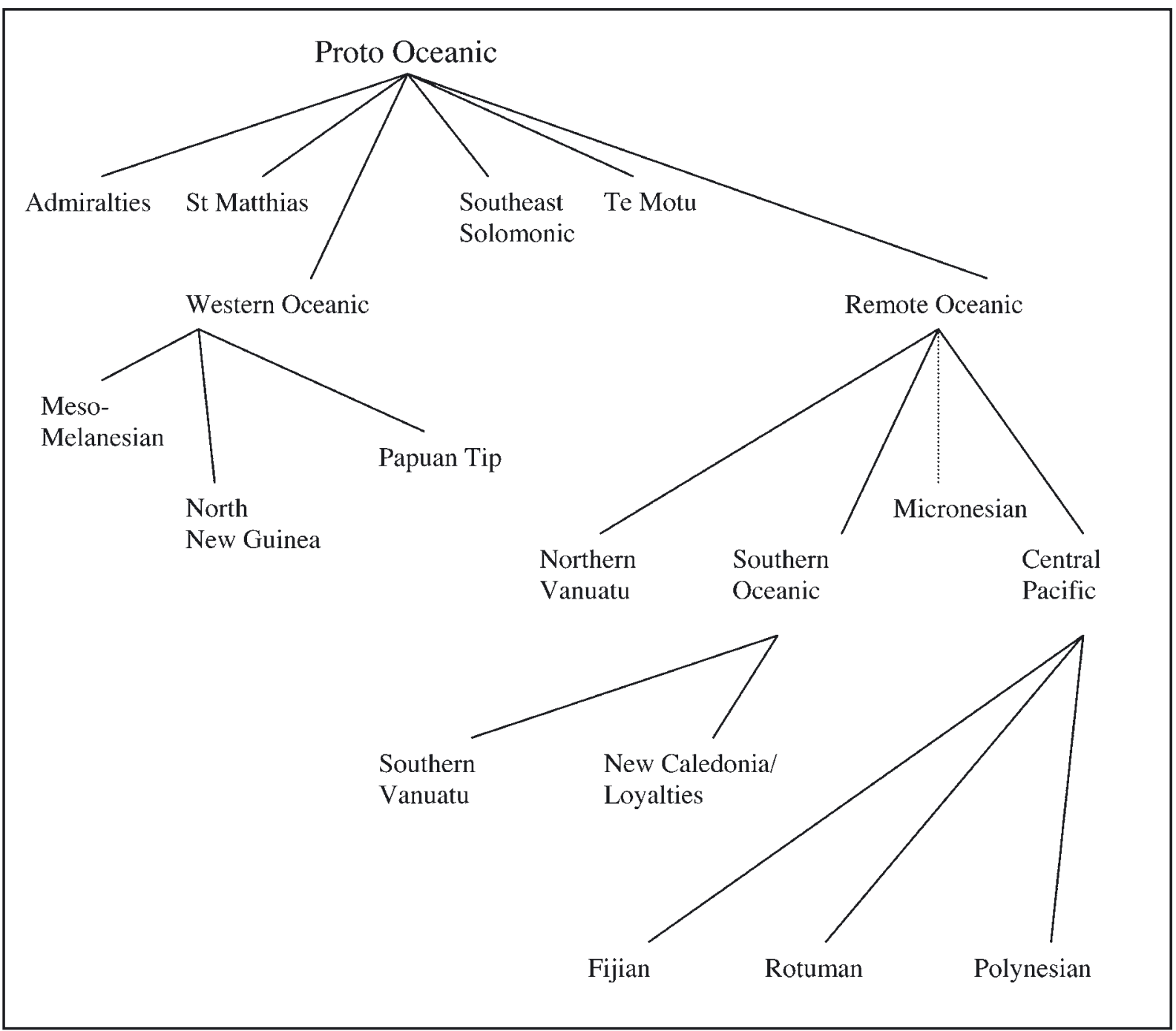

Figure 3. Internal classification of the Oceanic languages.

\section{Equating particular Austronesian stages with archaeological entities}

It seems reasonable to make the following equations between particular Austronesian stages and particular archaeological traditions (Bellwood 1997; Green 2003; Kirch and Green 2001).

Proto Austronesian

Proto Malayo-Polynesian

Proto Oceanic

Proto Central Pacific

Proto Polynesian
Neolithic cultures of Taiwan 5000-4,000 BP

Neolithic of the Batanes Is. and N. Luzon c. 4000-3600 BP

Early Lapita of the Bismarcks 3400-3100 BP

Lapita of Fiji-Tonga 3000-2900 BP

Post-Lapita cultures of the Tonga-Samoa region c. 2000-1500 BP 
As a consensus about the subgrouping of Austronesian has emerged, it has become ever more apparent that the initial spread of the Lapita culture and the initial dispersal of the Oceanic languages were part of one and the same event. The spread of Early Lapita across the Bismarck Archipelago around 3400-3300 BP can be equated with the first stage in the diversification of Oceanic into its surviving branches. When Lapita was carried into Remote Oceania, reaching Reefs / Santa Cruz, Vanuatu, New Caledonia, Fiji and Tonga, in the period 3200-2900 BP, all the indications are that the carriers spoke still mutually intelligible dialects of early Oceanic. There is no linguistic evidence for a lengthy pause at any point along the way, between the Bismarcks and West Polynesia, in the first few centuries after the breakup of POc. Such evidence would take the form of a sizeable body of innovations linking some languages located say, in the main Solomons group, to languages spoken further east, or linking languages of Vanuatu to the Fijian and Polynesian languages, or linking the Fijian languages to Polynesian. Insofar as any subgroups have been proposed along these lines, they rest on very few innovations - nothing that would require a pause of more than a century or two.

By contrast, there is ample evidence for some significant pauses in the expansion of Oceanic languages over Polynesia and Micronesia. The Polynesian subgroup is defined by a massive set of shared innovations, consistent with a period of common development of 1000 years or more in the West Polynesia area (Clark 1979; Pawley 1996a). The innovations defining Micronesian are not nearly so extensive but nonetheless point to a significant period of unity.

By contrast, evidence for a unified Proto Central Pacific (PCP) stage (ancestral to the Fijian and Polynesian languages and Rotuman) is slender. There is one phonological innovation, loss of * $R$ (e.g. POc *baRa 'fence > Standard Fijian baa, PPn *paa, POc *tiRo 'oyster' > S. Fijian tio, PPn *tio, POC *paqoRu 'new' $>$ S. Fijian vou, PPn *fo?ou. There are a few lexical innovations, e.g. POC *matuluR 'sleep' is replaced in PCP by a non-cognate word, " $m o ð e$, giving S. Fijian moðe, Rotuman mose, Tongan mohe, Maori moe, and a very few grammatical innovations, e.g. Fijian and PPn developed a preposition * $k i$ 'to towards' and came to use the locative preposition * ${ }^{i}$ to mark cause as well as location. The distribution of innovations indicates that PCP took the form of a chain of dialects centred in Fiji, possibly extending to Tonga, that the Polynesian branch diverged from the eastern part of this chain (Geraghty 1983) and that Rotuman diverged from the western part of this chain (Pawley 1996b).

\section{Reconstructing the lexicons of different stages of Austronesian}

The recoverable part of the lexicon of a prehistoric proto-language is that which has left residues, in the form of cognate vocabulary, detectable in daughter languages. How large that detectable residue will be depends on a number of different factors:

(1) The number of languages in the group. The more languages, the more witnesses there are to attest features of the proto-language.

(2) The quality of the descriptive data available for contemporary languages.

(3) The subgrouping or family tree structure. Agreement between a pair of closely related witnesses has a different value from agreement between a pair of distantly related languages.

(4) The time depth of the language group. The greater the time depth the more languages change and the smaller the residue of elements retained from the proto-language.

(5) How conservative the languages have been. The nature and rate of linguistic change will be shaped by the demographic and geographic history of speech communities, e.g. whether they were isolated or in close contact with other communities, how large the communities were, and whether they moved from one kind of environment to another, and so on. 
The Austronesian family has proved to be something of a historical lexicographer's paradise. Several factors have combined to make it easy to reconstruct a relatively high proportion of the lexicon of various stages. Austronesian is a very large family, with more than 1,000 member languages, and it has a highly structured family tree. Many of the subgroups are widely separated geographically, thereby reducing the problem of sorting out borrowings from shared inheritances. Some of the interstages (intermediate proto-languages) have many daughter languages, providing many independent witnesses when it comes to making decisions about reconstructions. The time depth of the family (the interval since the breakup of PAn) is not very great, probably on the order of 4000-5000 years.

The following is a brief account of works which give reconstructions with supporting cognate sets for particular stages of Austronesian that are relevant to the present discussion.

\section{Proto Austronesian, Proto Malayo-Polynesian, Proto Central-Eastern Malayo- Polynesian, Proto Eastern Malayo-Polynesian}

For lexical items attributed to these early stages by far the largest database is Blust's (1995a) Austronesian Comparative Dictionary (ACD), a computer file equivalent to several thousand pages of printout, based in the Department of Linguistics at the University of Hawaii. Blust's cognate sets in many cases also include Oceanic material and reconstructions attributed to POc. Other important sources for early Austronesian reconstructions with cognate sets are various articles by Blust (esp. 1970, 1972a, 1980a,b, 1982, 1983-84b, 1986, 1989, 1991, 1993, 1994).

\section{Proto Oceanic ${ }^{3}$}

An important source is the Lexicon of Proto Oceanic project based in the Department of Linguistics, Research School of Pacific and Asian Studies, The Australian National University. This aims to produce a six volume series that examines various semantic domains and critically evaluates cognate sets and reconstructions in each domain. Although the main body of reconstructions is at the level of POc, particular cognate sets allow reconstructions to be attributed to particular lower-order proto-languages, as well, as is the case with Blust's ACD. The first two volumes, dealing with material culture and with the physical environment, respectively, have been published (Ross et al. 1998, 2003). The third and fourth volumes, on plants and animals, respectively, are almost complete (most chapters have either been published separately or are available in electronic form). The fifth, dealing with people and society, is partly drafted, and the sixth is still in the planning stage. Other sources for POc cognate sets include Chowning (1991), Osmond (1998b, 2000), Ross (1988, 1996b), Pawley $(1982,1985,2005)$, and a number of papers in Pawley and Ross (1994).

\section{Proto Central Pacific}

There is no general compilation other than a problematic early attempt by Hockett (1976). But see Biggs (1965), Geraghty $(1983,1986,1990,1996)$, Ross et al. (1998, 2003, in prep.).

\section{Proto Polynesian}

The major source is Biggs and Clark (2006), which also contains many reconstructions for proto-languages of lower-level subgroups, such as Tongic, Nuclear Polynesian and Eastern Polynesian. See also Ross et al. (1998, 2003 , in prep.).

\section{Proto Admiralties.}

No general compilation but see Blust (1978b, 1996), Ross et al. (1998, 2003, in prep.).

\section{Proto Western Oceanic, Proto Meso-Melanesian, Proto North New Guinea, Proto Papuan Tip}

No general compilations but see Ross (1988), 1994, Ross et al. 1998, 2003, in prep.). 


\section{Proto Micronesian}

The main source is Bender et al. (2003a, b).

\section{Proto Central and North Vanuatu}

The main source is Clark (2007).

\section{Proto South Vanuatu}

The main source is Lynch (2001).

\section{Proto New Caledonia/Loyalties}

There is no general compilation but see Haudricourt (1971), Ozanne-Rivierre (1992, 1995), Ozanne-Rivierre and Rivierre (1989), Rivierre (1991).

\section{Proto Southeast Solomonic}

No general compilation but see Cashmore (1969), Levy (1980, Ross et al. (1998, 2003, in prep.).

A very rough indication of the number of lexical reconstructions made to date for certain stages of Austronesian is given below. The variations in the totals for different stages have to do both with the factors listed above and with the amount of work that has been done. ${ }^{4}$

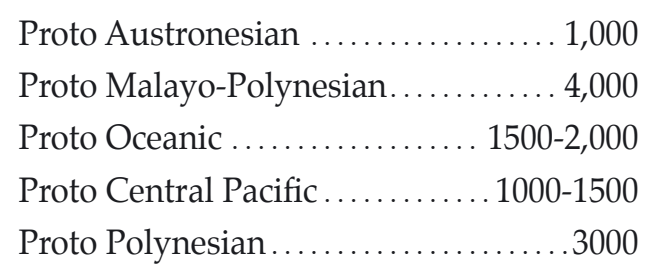

The total lexicon of an average Austronesian language spoken by a Neolithic community was probably in excess of 30,000 lexical units, counting each distinct sense of a word and each derived word and compound as a distinct lexical unit. By this measure 4,000 lexical units is just a small part of the total lexicon (though 4,000 roots would be a high proportion of the total number of roots). Even a set of 1000 reconstructions will typically include extensive terminologies for many fundamental domains of material and non-material culture and gives us a large body of material to work with.

\section{Lexical evidence for selected cultural domains}

This section gives reconstructed terminologies for 11 semantic fields in five Austronesian interstages: Proto Austronesian (PAn), Malayo-Polynesian (PMP), Proto Oceanic (POc), Proto Central Pacific (PCP) and Proto Polynesian (PPn). We are chiefly interested in the comparison between PMP and POc. PCP and PPn reflexes of POc reconstructions are included as well, to exemplify patterns of lexical retention and loss in languages associated with Lapita and post-Lapita archaeological traditions in the Fiji-West Polynesia area. Because of the large number of reconstructions treated the supporting cognate sets cannot be included and the discussion will necessarily be very sketchy. The reader is referred to the primary sources for supporting cognate sets and more detailed commentary.

\section{Canoes and sailing}

More than 20 terms for canoe parts and associated items are attributable to POc (Pawley and Pawley 1994). These includes names for parts of a five piece built up hull, end pieces, projecting parts of the outrigger complex, platform, sail, boom of sail, steering oar, paddles, bailers, rollers for beaching and launching canoes, and anchor, indicating that POc speakers built substantial ocean-going outrigger canoes. 
Thirteen of the POc terms continue PMP words (Blust 1995c). Several terms for parts of the canoe complex are missing from the PMP list, but in some cases we can infer that names for these items were present in PMP because their existence is logically implied by the presence of other terms, e.g. although there is no PMP etymon for 'outrigger float' the presence of PMP * $(c, s) a(R)$ man 'outrigger boom' indicates that it must have been present.

No term for double canoe is attributable to POc. PPn *fa?urua 'double canoe' (from *fa?u 'lashed, constructed (of house, canoe)', " rua 'two', i.e. two hulls lashed together) is well supported, e.g. by Rennellese ha?ugua, Maori hourua, Tuvalu foulua 'double canoe'. Compare also Samoan fou-lua-lua 'bind together, as 2 canoes', Tongan fo?u-vaka 'build a canoe'. Forms outside of Polynesian that resemble PPn *fa?urua, e.g. Kiribati baurua, Lau (Malaita) foorua, are very probably loans from Polynesian sources. Fijian drua 'twin, double canoe' is likely a separate development. Terms for double canoes in South East Papua and New Caledonia are not related to the Polynesian cognate set.

Table 1: Terms for canoes and sailing

1. Terms continued from PMP

\begin{tabular}{|c|c|c|c|c|c|}
\hline & PAn & PMP & POc & PCP & PPn \\
\hline prop, post, mast & *tuku & ${ }^{*}$ tuku & *tuku & ${ }^{*}$ tuku ${ }^{1}$ & ${ }^{*}$ tuku \\
\hline boat rollers & & *layen & *layon & *layo & *layo \\
\hline outrigger canoe or hull ${ }^{2}$ & & ${ }^{*}$ katiR & ${ }^{*}$ kati(R) & & \\
\hline outrigger float & & ${ }^{*}(\mathrm{c}, \mathrm{s}) \mathrm{a}(\mathrm{R}) \mathrm{man}$ & *saman & *ðama & *hama \\
\hline sail & *layaR & *layaR & *layaR & *laða & *laa \\
\hline steering oar, steer & & ${ }^{*}$ quli(n, $\left.\mathrm{y}\right)$ & *qulin & ${ }^{*}$ quli & *quli \\
\hline canoe paddle & & ${ }^{*}$ be $(\mathrm{R})(\mathrm{c}, \mathrm{s}) \mathrm{ay}$ & ${ }^{*}$ pose & *voðe & ${ }^{*}$ fohe \\
\hline to paddle & & ${ }^{*}$ pa-luja & *paluca & & \\
\hline punting pole & & *teken & *tokon & ${ }^{*}(\mathrm{i})$ toko & *toko \\
\hline bailer & & ${ }^{*} \operatorname{limas}$ & *(l,n)ima(s) & *(i)nima & \\
\hline anchor & & ${ }^{*}$ sauq & *jau(q) & *jau & ${ }^{*}$ tau \\
\hline channel in reef & & ${ }^{*} \operatorname{sawa}(\mathrm{\eta}, \mathrm{q})$ & *saway & *sawa & *awa \\
\hline make a sea voyage & & ${ }^{*}$ pa-lahud & ${ }^{*}$ palau $(\mathrm{r})$ & ${ }^{*}$ volau & ${ }^{*}$ folau \\
\hline load a vessel; cargo & & *lujan & *lujan & *uja & *uta \\
\hline embark, ride on a vessel & & *sankay & *sake & *ðake & \\
\hline raft & & ${ }^{*}$ dakit & ${ }^{*} \operatorname{raki}(\mathrm{t})$ & & \\
\hline
\end{tabular}

2. Terms continued from POc, without known antecedents in PMP

\begin{tabular}{llll} 
& POc & PCP & PPn \\
\hline canoe, sailing canoe & ${ }^{*}$ waga & ${ }^{*}$ waga & ${ }^{*}$ waka \\
topstrake & ${ }^{*}(\mathrm{q})$ oRa & ${ }^{*}$ (q)oa & ${ }^{*}(\mathrm{q})$ oa \\
outrigger boom & ${ }^{*}$ kiajo & ${ }^{*}$ kiajo & ${ }^{*}$ kiato \\
sticks attaching float & ${ }^{*}$ patoto & ${ }^{*}$ vatoto & ${ }^{*}$ fatoto \\
side opposite outrigger & ${ }^{*}$ katae & ${ }^{*}$ katae & ${ }^{*}$ katea \\
boom/yard of sail & ${ }^{*}$ jila & ${ }^{*}$ sila & ${ }^{*}$ tila \\
bow of boat & ${ }^{*}$ muqa & ${ }^{*}$ muqa & ${ }^{*}$ muqa \\
prow, end-piece of prow & ${ }^{*}$ (i,u)cun & ${ }^{*}$ isu & ${ }^{*}$ isu \\
stern & ${ }^{*}$ muri & ${ }^{*}$ muri & ${ }^{*}$ muri \\
landing place & ${ }^{*}$ mata-sawan & ${ }^{*}$ mata-sawa \\
boat owner & ${ }^{*}$ tau (ni) waga ${ }^{*}$ tau (ni) waga "tau waka
\end{tabular}


3. PAn/PMP terms without known reflexes in Oceanic

PAn

PMP

boat, canoe $\quad$ *qabay $\quad$ *qabay

Notes: 1. PCP and PPn *tuku 'running stay supporting sail'. 2. In various Western MP languages reflexes mean 'outrigger float', 'provide a boat with outrigger'.

\section{Architecture and settlement patterns}

Seventeen PMP terms have been reconstructed for types of house and parts of the house (Green and Pawley 1999). POc retains 11 of these and has another six that have no known cognates in PMP. The POc house terms point to solidly built rectangular houses, sometimes raised on stilts, with thatched gable roofs. The existence of a term for 'village' or 'nucleated settlement' in POc is uncertain. *panua and *pera are candidates. *panua is a polysemous word whose senses included 'land', 'inhabited place' and probably 'people of a community', and it has reflexes that mean 'village' in various languages (Pawley 2005).

Table 2: Terms for house and settlement patterns

1. POc terms continued from PAn and PMP

\begin{tabular}{llll} 
& PAn & PMP & POc \\
\hline house & ${ }^{*}$ Rumaq & ${ }^{*}$ Rumaq & ${ }^{*}$ Rumaq \\
post & "SadiRi & ${ }^{*}$ hadiRi & ${ }^{*}$ aRiRi \\
\hline
\end{tabular}

2. Terms continued from PMP

\begin{tabular}{|c|c|c|c|c|}
\hline & PMP & POc & PCP & PPn \\
\hline open-sided building & *balay & ${ }^{*}$ pale & ${ }^{*}$ vale $^{1}$ & ${ }^{*}$ fale \\
\hline men's house & *kamaliR & ${ }^{*}$ kamali(R) & & \\
\hline hut, temporary shelter & *udun & *uru(n) & & ${ }^{*} \mathrm{uru}^{2}$ \\
\hline ridgepole & *bubun & *pupun-an & ${ }^{*}$ vuvu & $*(\operatorname{taqu}) \mathrm{fufu}$ \\
\hline sago thatch & *qatep & *qatop & ${ }^{*}$ qato & ${ }^{*}$ qato \\
\hline thatch & *daSun & ${ }^{*} \operatorname{rau}(\mathrm{n})$ & * rau & * rau \\
\hline rafter & *kasaw & ${ }^{*}$ kaso & ${ }^{*}$ kaso & *kaso \\
\hline prepare thatch for roofing & ${ }^{*}$ sasa(h,q) & ${ }^{*}$ saja(q) & & \\
\hline secure thatch with battens & *kapit & ${ }^{*}$ kapit & & \\
\hline post & *turus & ${ }^{*}$ turu(s) & $*(t, d)$ uru & \\
\hline crossbeam & *senkar & *soka(r) & *ðoka & *soka \\
\hline platform, shelf & *pa(n)tar & *patar & *vata & ${ }^{*}$ fata \\
\hline storage rack & ${ }^{*} \mathrm{pa}(\mathrm{l}, \mathrm{R}) \mathrm{a}$ & ${ }^{*} \mathrm{pa}(\mathrm{r}, \mathrm{R}) \mathrm{a}$ & ${ }^{*}$ vara & \\
\hline ladder, bridge, notched log & *titey & *tete & & \\
\hline board, plank & *papan & *baban & *baba & *papa \\
\hline wooden peg & ${ }^{*} \operatorname{pak}(\mathrm{o}, \mathrm{u})$ & ${ }^{*}$ pako & *(i)vako & ${ }^{*}$ faqo \\
\hline fireplace & *dapuR & ${ }^{*} \operatorname{rapu}(\mathrm{R})$ & *dravu & ${ }^{*}$ refu \\
\hline fence & ${ }^{*} \mathrm{ba}(\mathrm{l}, \mathrm{r}, \mathrm{R}) \mathrm{a}$ & ${ }^{*} \mathrm{baRa}$ & *baa & *paa \\
\hline land, inhabited place, etc. & *banua & *panua & *vanua & *fanua \\
\hline
\end{tabular}


3. Terms continued from POc, but without known antecedents in PMP

\begin{tabular}{llll} 
& POc & PCP & PPn \\
\hline area under house on stilts & ${ }^{*}$ gabwari & & \\
doorway & ${ }^{*}$ kataman & & \\
main bearer & ${ }^{*}$ bou & ${ }^{*}$ bou & ${ }^{*}$ pou \\
partition & ${ }^{*}$ logi & ${ }^{*}$ logi & ${ }^{*}$ loki \\
stone oven & ${ }^{*}$ qumun & ${ }^{*}$ qumu & ${ }^{*}$ qumu \\
boundary marker & ${ }^{*}$ bayat & ${ }^{*}$ bai & ${ }^{*}$ pae \\
cleared area, ? village centre & ${ }^{*}$ mwalala & ${ }^{*}$ pwalala & \\
? public space, village green & ${ }^{*}$ malaqi & ${ }^{*}$ mala?(e,i) & ${ }^{*}$ mala?e \\
? settlement, village & * pera & & \\
\hline
\end{tabular}

4. PAn and/or PMP terms without known reflexes in POc

\begin{tabular}{|c|c|c|}
\hline & PAn & PMP \\
\hline shed, shelter & *sapaw & *sapaw \\
\hline hamlet & ${ }^{*}$ kuan & ${ }^{*}$ kuan \\
\hline bamboo split, flattened & ${ }^{*}$ saqsaq & *saqsaq \\
\hline peel rattan, bamboo & ${ }^{*} \mathrm{rauC}$ & ${ }^{*}$ raut \\
\hline mat & *Sikam & *hikam \\
\hline mat & & *lamak \\
\hline notched log, ladder & & *haRezan \\
\hline room & & *bilik \\
\hline roof, ridge & & *ubun \\
\hline crossbeam & & *atan \\
\hline
\end{tabular}

Notes: 1. PCP *vale 'house, dwelling'. 2. Tongan uu 'sheltered'. 3. POc * qumun 'stone oven' has a cognate in at least one non-Oceanic language of Maluku.

\section{Fishing technology and methods}

Fishing and collecting sea invertebrates were clearly very important parts of the economy of PMP and POc speakers. Table 3 lists 28 POc terms for fishing technology and methods (Osmond 1998b). Continued from POc are names for one kind of fish net, fishnet float, basketry fish trap, fishing line and pole, spear, corral, fish drive, fish poison continued from PMP (Blust 1995c). Several other POc terms having to do with fishing have no known etyma in PMP, including two for kinds of net, one for netting needle and one for dragline.

About 140 POc terms for kinds of fish have been reconstructed (Osmond in prep.) and another 50 or so terms for kinds of molluscs, crustaceans and echinoderms (Pawley 1996c) - too many to be listed here. The totals for PMP are not much smaller. As ethnographic observations show (Dye 1983; Kirch and Dye 1979) different kinds of fish require different capture methods. Thus, indirect evidence for several fishing techniques can be found in the archaeological record, in the range of fish species caught (Walter 1989). 
Table 3: Terms for fishing methods and technology

1. POc terms continued from $P A n$ and/or PMP

\begin{tabular}{|c|c|c|c|c|c|}
\hline & PAn & PMP & POc & PCP & PPn \\
\hline fishing line & & *hapen & *apon & *avo & *afo \\
\hline fishhook & ${ }^{*}$ kawil & *kawil & ${ }^{*}$ kawil & ${ }^{*} \mathrm{kau}$ & *kau \\
\hline bait, trolling lure & *paen & *paen & *bayan & *baya & *paa \\
\hline bait & & *bayi & *bani & *bani & *pani \\
\hline basketry fish trap & *bubu & *bubu & *pupu & ${ }^{*}$ vuvu & \\
\hline seine net & & *puket & ${ }^{*}$ pukot & & \\
\hline fish net, ? dip net & & *lawa(n,q) & ${ }^{*} \operatorname{lawa}(\mathrm{n}, \mathrm{q})$ & *lawa & ${ }^{*}$ lawa $^{1}$ \\
\hline cowrie shell sinker & & *buliq & *buli(q) & *buli & ${ }^{*}$ pule \\
\hline fishnet float & & *apun & *apu-apun & & \\
\hline fish drive & & ${ }^{*}$ kebuR & ${ }^{*} \mathrm{kopu}(\mathrm{R})$ & ${ }^{*} \mathrm{kovu}^{2}$ & ${ }^{*}$ kofu \\
\hline derris fish poison & & *tuba & *tupa & *tuva & \\
\hline torch, fish with torch & & *damaR & ${ }^{*}(\mathrm{~d}) \mathrm{ramaR}$ & ${ }^{*}$ rama & ${ }^{*}$ rama \\
\hline spear & & ${ }^{*}$ saet & ${ }^{*} \mathrm{sao}(\mathrm{t})$ & *jao & *tao \\
\hline fish corral & & *belat & ${ }^{*}$ polat & ${ }^{*}$ vola & \\
\hline
\end{tabular}

2. POc terms without known antecedents in PMP

\begin{tabular}{|c|c|c|c|}
\hline & POc & PCP & PPn \\
\hline fish hook & ${ }^{*} \operatorname{ta}(g, k) o$ & ${ }^{*} \mathrm{ta}(\mathrm{a}, \mathrm{o}) \mathrm{ko}$ & ${ }^{*} \mathrm{t}(\mathrm{a}, \mathrm{o}) \mathrm{ko}$ \\
\hline fish net & ${ }^{*}$ reke & ${ }^{*}$ dreke $^{3}$ & ${ }^{*}$ reke \\
\hline fish net, ? with handle or frame & ${ }^{*} \mathrm{kup}(\mathrm{w}) \mathrm{ena}$ & ${ }^{*}$ kube $(\mathrm{n}, \mathrm{\eta}) \mathrm{a}$ & ${ }^{*}$ kupena \\
\hline float of fishnet & *uton & *uto & *uto \\
\hline mesh of fishnet & ${ }^{*}$ mata & ${ }^{*}$ mata & ${ }^{*}$ mata \\
\hline netting needle & *sika & *sika & *sika \\
\hline dragline & ${ }^{*} \operatorname{rau}(\mathrm{n})$ & *rau & *rau \\
\hline stone fish weir & *baRa & *baa & *paa \\
\hline fish spear & ${ }^{*} \mathrm{kuj}(\mathrm{i}, \mathrm{u}) \mathrm{r}$ & & \\
\hline spear with prong & *tara & *tara & ${ }^{*}$ tala ${ }^{4}$ \\
\hline spear retained in hand & ${ }^{*}$ sua & ${ }^{*}$ sua $(\mathrm{k})$ & *sua \\
\hline gather seafood on reef & *payoda & *vanoda & *fayota \\
\hline seafood gathered on reef & ${ }^{*}$ p-in-ayoda & *vinayoda & *finayota \\
\hline torch, fish at night with torches & *(d)rama(R) & *rama & *rama \\
\hline
\end{tabular}

Notes: 1. PPn *lawa 'wrap in sennet'. 2. PCP *kovu 'wrap up fish, etc. 3. PCP *dreke 'pocket in a net'. 4. Tongan tala 'spike, barb', Samoan tala 'spike, prong'

\section{Agriculture and aboriculture}

Some 20 terms for agricultural activities and artefacts are attributable to POc (French-Wright 1983; Osmond 1998a). A dozen or so of these are continued from PMP (Blust 1995c, ACD), including terms for garden or swidden, cleared land, fallow land, weed gardens, plant in holes and sow seed. POc has another eight or so terms that lack known PMP antecedents. 
Table 4: Terms relating to gardening activities

1. POc terms continued from PAn/PMP

\begin{tabular}{|c|c|c|c|c|c|}
\hline & PAn & PMP & POc & РCP & PPn \\
\hline garden, swidden & *qumah & *quma & *quma & *uma & \\
\hline bushland, hinterland & *quCan & ${ }^{*}$ qutan & *qutan & ${ }^{*}$ quta $^{1}$ & ${ }^{*}$ quta \\
\hline land cleared for garden & *tebaS & ${ }^{*}$ teba & ${ }^{*}$ topa & ${ }^{*}$ tova & ${ }^{*}$ tofa $^{2}$ \\
\hline fence & * qa(1,R)ad & *qalad & ${ }^{*} \mathrm{qaRa}(\mathrm{r})$ & *qaa & *qaa \\
\hline fallow land & & *talun & ${ }^{*}$ talu(n) & *talu & *talu-talu \\
\hline burn fields & & ${ }^{*}$ zeket & *soko(t) & & \\
\hline pull weeds & ${ }^{*} \mathrm{buCbuC}$ & *butbut & ${ }^{*} \operatorname{pupu}(\mathrm{t})^{3}$ & ${ }^{*}$ vuvu & ${ }^{*} \mathrm{fufu}^{4}$ \\
\hline weed garden & & *babaw & ${ }^{*}$ papo & *vovo & \\
\hline plant in holes & & *hasek & *asok & & \\
\hline sow seed & & ${ }^{*}$ kambuR & ${ }^{*} k a b u(R)$ & *kabu & ${ }^{*} \mathrm{kapu}^{5}$ \\
\hline
\end{tabular}

2. POc terms without known antecedents in PMP

\begin{tabular}{|c|c|c|c|}
\hline hoe, adze & ${ }^{*}$ salu & ${ }^{*}$ saru & ${ }^{*}$ salu \\
\hline strip vegetation & ${ }^{*}$ sani & ${ }^{*}$ sani & *sani \\
\hline clear rubbish & *sara & *ðara & \\
\hline digging stick & ${ }^{*}$ waso & & \\
\hline bury, plant tuber & *tanum & ${ }^{*}$ tanum & ${ }^{*} \tan u$ \\
\hline make yam mound & $*(\mathrm{p}, \mathrm{b}) \mathrm{uk}(\mathrm{i}, \mathrm{e})$ & *buke & ${ }^{*}$ puke \\
\hline break up ground & *suar & ${ }^{*}$ sua & *sua \\
\hline garden fence & ${ }^{*} \mathrm{kaRi}$ & & \\
\hline fence, boundary marker & *bayat & *bai & ${ }^{*}$ pae \\
\hline
\end{tabular}

Notes: $1 . P C P{ }^{*}$ quta 'land, as from the sea; inland, as from the coast'. 2. PPn *tofa 'open up something new'. 3. POc * pupu(t) 'pluck fruit'. 4 PPn *fufu 'strip off, as leaves, fibre'. 5. PPn *kapu 'spread over, surround, envelop'.

A major change in POc was the loss of the PMP rice and millet terminology, including terms for granary, pestle and mortar. This is consistent with the widely accepted view that the Austronesian speakers who entered Northwest Melanesia in the second half of the 2nd millennium BC had completely abandoned the cultivation of grain crops.

Table 5: PAn/PMP terms relating to grain crops, which lack known reflexes in POc

\begin{tabular}{|c|c|c|}
\hline & PAn & PMP \\
\hline rice plant & *pajay & ${ }^{*}$ pajay \\
\hline seed rice for planting & *bineSiq & *binehiq \\
\hline husked rice & *beRas & *beRas \\
\hline cooked rice & *Semay & *hemay \\
\hline foxtail millet & *beCen & *beten \\
\hline chase (birds etc.) from field & *buRaw & *buRaw \\
\hline harvest & *qanih & *qanih \\
\hline thresh by trampling & *(e,i)Rik & *eRik \\
\hline
\end{tabular}




\begin{tabular}{|c|c|c|}
\hline thresh by beating & *paspas & ${ }^{*}$ paspas \\
\hline winnow & *tapeS & *tapeh \\
\hline rice straw & ${ }^{*}$ zaRami & ${ }^{*}$ zaRami \\
\hline pestle & *qaSelu & ${ }^{*}$ qahelu \\
\hline mortar & *lesun & *lesun \\
\hline hut, granary & *lepaw & *lepaw \\
\hline canal, ditch & *kali & ${ }^{*}$ kali \\
\hline pull out weeds & ${ }^{*}$ SebuC & *hebut \\
\hline
\end{tabular}

POc retained PMP terms for three root crops (taro, Alocasia taro and the greater yam), Musa bananas and sugar cane. It also retained PMP terms for a good many useful trees and other plants. A very large set of POc terms is reconstructable for useful trees (Ross 1996b, Ross et al in prep.; Tryon 1994) pointing to the importance of tree culture in the economy. Table 6 includes a selection of these.

Table 6: Terms for root and fruit crops and other useful plants

1. POc terms continued from $P A n / P M P$

\begin{tabular}{|c|c|c|c|c|c|}
\hline & PAn & PMP & POc & PCP & PPn \\
\hline giant taro, Alocasia indica & *biRaq & *biRaq & *piRaq & ${ }^{*}$ via $^{1}$ & \\
\hline sugar cane & ${ }^{*}$ CebuS & *tebu & *topu & *dovu & *too \\
\hline yam, Dioscorea alata & & *qubi & *qupi & ${ }^{*}$ quvi & ${ }^{*}$ qufi \\
\hline taro, Colocasia & & *tales & *talo(s) & *talo & *talo \\
\hline banana, Musa hybrids & & *punti & *pudi & ${ }^{*}$ vudi & ${ }^{*}$ futi \\
\hline breadfruit, Artocarpis atilis & & ${ }^{*}$ kuluR & ${ }^{*}$ kuluR & ${ }^{*}$ kulu & ${ }^{*}$ kulu \\
\hline sago, Metroxylon sp. & & ${ }^{*}$ Rambia & *Rabia & ${ }^{*} \mathrm{abia}^{1}$ & \\
\hline cordyline & & ${ }^{*} \mathrm{siRi}$ & *jiRi & *jii & ${ }^{*} \mathrm{sii}$ \\
\hline coconut & & *niuR & *niuR & *niu & ${ }^{*}$ niu \\
\hline pandanus & & *paydan & *padran & *vadra & ${ }^{*}$ fara \\
\hline coastal pandanus & & ${ }^{*} \mathrm{kiRay}^{2}$ & ${ }^{*} \mathrm{kiRe}$ & ${ }^{*}$ kie-kie & ${ }^{*}$ kie-kie \\
\hline Barringtonia & & *butun & ${ }^{*}$ putun & ${ }^{*}$ vutu & \\
\hline mango, prob. Mangifera indica & & *pahuq & *pau(q) & & \\
\hline mango, generic & & *wai & *wai & & \\
\hline Indian almond, Terminalia sp. & & *talisay & *talise & *taliðe & ${ }^{*}$ talie \\
\hline chestnut, Inocarpus sp. & & *(q)ipi & *qipi & *ivi & $*_{\text {ifi }}$ \\
\hline \multicolumn{6}{|l|}{ Canarium almond, } \\
\hline Canarium indicum ${ }^{3}$ & & *kanaRi & ${ }^{*} \mathrm{ka \eta} a \mathrm{Ri}$ & & ${ }^{*}$ makari ${ }^{3}$ \\
\hline Burckella obovata & & *natu & 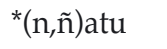 & & \\
\hline citrus spp. & & *limaw & ${ }^{*}$ molis & ${ }^{*}$ moli & ${ }^{*}$ moli \\
\hline ginger, Zingiber sp. & & *laqia & *laqia & *laya & \\
\hline curcurbit & & ${ }^{*}[\mathrm{ka}]$ timun & ${ }^{*}[\mathrm{ka}]$ timun & *timo & *timo \\
\hline chew on sugar cane & & *ququs & ${ }^{*}$ ququ(s) & & \\
\hline
\end{tabular}


2. POc terms without known antecedents in PMP

potato yam, Dioscorea bulbifera

taro, Colocasia

taro seedling

prepare yam for planting

cut seed yams for planting

banana (Australimusa group)

k.o. cooking banana

breadfruit

core of breadfruit

Abelmoschus manihot

Paper mulberry, Broussonetia papyrifera

Malay apple, Syzygium malaccense

Polynesian plum, Pometia pinnata ${ }^{4}$

Indian mulberry, Morinda citrifolia

Indian mulberry, Morinda citrifolia

Vi apple, Spondias dulcis

Canarium almond, Canarium indicum

turmeric

large pandanus

edible wild cane

\begin{tabular}{|c|c|c|}
\hline *mwapo(q) & ${ }^{*}$ mavu & ${ }^{*}$ mafu \\
\hline \multicolumn{3}{|l|}{ *upea } \\
\hline \multicolumn{3}{|l|}{ *sopu } \\
\hline *paji & *vaði & \\
\hline *joRaga & ${ }^{*}$ soaga & ${ }^{*}$ soaka \\
\hline \multicolumn{3}{|l|}{ *sakup } \\
\hline \multicolumn{3}{|l|}{ *baReko } \\
\hline${ }^{*}$ malo & ${ }^{*}$ malo & ${ }^{*}$ malo \\
\hline \multicolumn{3}{|l|}{${ }^{*}$ was $(\mathrm{i}, \mathrm{a})$} \\
\hline${ }^{*} \mathrm{~m}(\mathrm{w})$ ase & ${ }^{*}$ masi & \\
\hline *kapika & ${ }^{*}$ kavika & ${ }^{*}$ kafika \\
\hline *tawan & *tawa & ${ }^{*}$ tawa \\
\hline *ñoñum & *ก̃oñu & ${ }^{*}$ nonu \\
\hline *kurat & ${ }^{*}$ kura & \\
\hline *quRis & *uRi & ${ }^{*}$ wii \\
\hline \multicolumn{3}{|l|}{ *qalip } \\
\hline *yayo & *yano & *ayo \\
\hline${ }^{*} \mathrm{p}(\mathrm{w})$ asa & ${ }^{*}$ vasa & ${ }^{*}$ fasa \\
\hline${ }^{*}$ pijo & *viðo & ${ }^{*}$ fiso \\
\hline
\end{tabular}

Notes: 1. Bauan Fijian abia, arrowroot. 2. PCEMP *kanaRi. 3. PPn *makari ‘Canarium samoensis'. 4. PEMP *tawan.

\section{Domestic animals}

Two terms for 'pig' are reconstructable in PMP. Blust (1995c) argues that one term ("beRek) referred solely to domestic pigs and the other ("babuy) was a generic name for pigs, and was used in compounds to denote categories of pig and pig-like animals. At any rate, only *beRek was retained in POc. There is some evidence for a second POc term for 'pig, (?) sow', *bukas, which had no PMP etymon.

No POc term for 'domestic fowl, chicken' is well supported, although chicken bones occur in Early Lapita sites. The PMP name for the domestic fowl, *manuk, appears in POc as the generic for 'bird' (Clark 1994).

PMP had a generic term for ' $\mathrm{dog}^{\prime}$ but this was not preserved in POc. There are several candidates for a POc term for 'dog' but all are problematic to some extent (Hudson 1989). This is consistent with the absence of dog remains from early Lapita sites. Its earliest appearance is in Reefs/Santa Cruz plainware assemblages dating to about $2600 \mathrm{BP}$, after which it disappears (R. Green pers. comm.).

Table 7: Terms for domestic animals

1. PAn/PMP terms without known reflexes in POc

\begin{tabular}{lll} 
& PAn & PMP \\
\hline pig & *babuy & *babuy \\
dog & *asu, wasu & *asu \\
rooster & & *lalun \\
\hline
\end{tabular}


2. POc terms continued from PAN/PMP

\begin{tabular}{llllll} 
& PAn & PMP & POc & PCP & PPn \\
\hline pig & *beRek & ${ }^{*}$ beRek & ${ }^{*}$ boRok & ${ }^{*}$ bwoo & \\
fowl & & "manuk & ${ }^{*}$ manuk (bird) ${ }^{*}$ manu & ${ }^{*}$ manu \\
\hline
\end{tabular}

3. POc terms without known antecedents in PMP

pig

*(b,p)ukas * * * * $\quad$ puaka

\section{Pottery, wooden vessels}

Names for four distinct kinds of ceramic vessel can be reconstructed for PMP (Blust 1995c). (It is curious that none have known PAn etyma, although the archaeological record for Taiwan makes it clear that pottery was made by PAn speakers.) At least three of the PMP terms were continued in POc (Osmond and Ross 1998). A number of other terms for food and water containers are reconstructable for POc, most of which lack PMP antecedents.

Table 8: Terms for pottery and other vessels used for holding food and liquid

1. POc terms continued from PMP

\begin{tabular}{|c|c|c|c|c|}
\hline & PMP & POc & PCP & PPn \\
\hline 1. cooking pot 2. generic for pots & ${ }^{*}$ kuDen & ${ }^{*}$ kuron & *kuro & ${ }^{*}$ kuro \\
\hline shallow pot & *balana & *palana & & \\
\hline large pot & *bayaq & *bwana & & \\
\hline narrow-necked jar & *kalalan & *kalala (?) & & \\
\hline trivet & *dalikan & & & \\
\hline drinking vessel & & ${ }^{*} \mathrm{ibu} / \mathrm{ubi}$ & ${ }^{*} \mathrm{ibu}$ & *ipu \\
\hline ladle, dipper & *kanbuq & ${ }^{*} \mathrm{kabu}$ & ${ }^{*} \mathrm{kabu}$ & ${ }^{*}$ kapu \\
\hline
\end{tabular}

\begin{tabular}{lll} 
2. POc terms which lack known antecedents in PMP & \\
\hline wooden bowl & ${ }^{*}$ tabiR(a,i) & ${ }^{*}$ tabili \\
coconut shell container & ${ }^{*} \mathrm{~b}(\mathrm{w})$ ilo & ${ }^{*}$ bilo \\
coconut shell half cup & ${ }^{*}$ lasa & \\
cup, ladle & ${ }^{*}$ kulopi & \\
water-bottle & ${ }^{*}$ wai $(\mathrm{p})$ & \\
\hline
\end{tabular}

\section{Cooking}

A small set of cooking terms can be reconstructed (Lichtenberk and Osmond 1998)

Table 9. Terms relating to cooking

1. POc terms continued from PMP

\begin{tabular}{|c|c|c|c|c|c|}
\hline & PAn & PMP & POc & PCP & PPn \\
\hline roast on fire & ${ }^{*}$ Cunuh & *tunu & *tunu & *tunu & ${ }^{*}$ tunu \\
\hline cook by boiling & *nasuq & *nasuq & ${ }^{*} \operatorname{nasu}(\mathrm{q})$ & & \\
\hline preserve by smoking & ${ }^{*}$ Capa & *tapa & *tapa & & \\
\hline eat raw (meat) & *qetaq & *qetaq & *(k,q)oda & ${ }^{*}$ qoda & *?ota \\
\hline
\end{tabular}


2. POc terms which lack known antecedents in PMP

\begin{tabular}{lcc}
\hline earth oven ${ }^{1}$ & ${ }^{*}$ qumun & ${ }^{*}$ qumu \\
steam-bake in stone oven & ${ }^{*}$ papi & ${ }^{*}$ vavi \\
steam-bake in stone oven & ${ }^{*}$ taqo & ${ }^{*}$ ta?o \\
cooked, burnt, lit & ${ }^{*}$ mwaRi & ta?o \\
\hline
\end{tabular}

Note: 1 . A cognate occurs in a SHWNG language, supporting the reconstruction of PEMP *qumun.

\section{Cutting and piercing instruments}

POc retained PMP *kiRam, which was almost certainly the generic term for axe/adze, along with the term for axe/adze handle. POc had a second term for axe/adze but there are no clues to how it differed in reference from *kiRam. Two terms for cutting tools are continued from PMP, one made of turtle shell (named after the Hawksbill turtle), the other, probably, of bamboo. POc continues PMP *saRum '(bone) needle'. Oceanic reflexes commonly apply to bat-wing needles used for tattooing.

POc *nad(r)i appears to have been a general term for any kind of stone whose flakes have a very sharp edge, such as obsidian, chert and flint. There is, however, a PWOc reconstruction for obsidian, ${ }^{*} \mathrm{qa}(\mathrm{r}, \mathrm{R}) \mathrm{in}$, that may continue a POC etymon that has been lost elsewhere.

Table 10: Terms for cutting implements and processes

1. POc terms continued from PMP

\begin{tabular}{|c|c|c|c|c|}
\hline & PMP & POc & РCP & PPn \\
\hline axe or adze & ${ }^{*}$ kiRam & *kiRam & ${ }^{*}$ kia & \\
\hline cutting implement of turtle shell & ${ }^{*} \mathrm{ta}(\eta) \mathrm{kub}$ & ${ }^{*} \operatorname{taku}(\mathrm{p})$ & *taku & *taku \\
\hline bone needle, awl ${ }^{1}$ & *zaRum & *saRum & *sau & *sau \\
\hline adze/axe handle & ${ }^{*}$ paRada & ${ }^{*}$ paRara & *vara & \\
\hline to hew, plane & *taRaq & *taRaq & *taa & \\
\hline bamboo knife & ${ }^{*}$ pisaw & ${ }^{*}$ piso & & \\
\hline cutting edge, sharp point & ${ }^{*}$ mata & *mata & *mata & ${ }^{*}$ mata \\
\hline grind, grate, sharpen like this & *asaq & *asaq-i & *asa & *asa \\
\hline file, rasp & ${ }^{*}$ kir-kir & ${ }^{*}$ kiri & & \\
\hline
\end{tabular}

2. POc terms which lack known antecedents in PMP

\begin{tabular}{lll} 
& POc & PCP \\
\hline axe, adze & ${ }^{*}$ matau & ${ }^{*}$ matau \\
stone with sharp cutting edge: obsidian, chert, flint & ${ }^{*}$ matau \\
pierce, bore a hole & ${ }^{*}$ nad(r)i \\
\hline
\end{tabular}

Note: 1 . Reflexes often refer to tattooing needle, typically made of wing bone of fruit bat (Osmond and Ross 1998:87).

\section{Clothing, weaving, ornaments and decoration}

Blust (1995c:493-494) argues that weaving and bark cloth manufacture were both practised by PAn, PMP and POc societies, though with different emphases. PMP clothing was probably chiefly made from woven cloth, as indicated by the considerable number of terms relating to weaving of garments that can be reconstructed. None of these terms have known reflexes in POc, which may point to a greater use of bark cloth. No reflexes of PMP *qatip 'backstrap loom' are known from Oceanic languages. Although Blust observes that the backstrap loom occurs in several Oceanic societies (in the Banks Is., the Carolines and Santa Cruz) and that this distribution suggests that it was known to POc speakers, the ethnographic record indicates that the loom 
spread to Melanesia more recently through Micronesia and Polynesian Outliers. Several POc words for items of clothing and ornamentation (Osmond and Ross 1998) have no known antecedents in PMP.

PMP terms for a Trochus armband (same term as for the shell itself) and comb persisted in POc.

Table 11: Terms for clothing, weaving, ornaments and decoration

1. PAn/PMP terms without known reflexes in POc

\begin{tabular}{|c|c|c|}
\hline & PAn & PMP \\
\hline to weave & ${ }^{*}$ tenun & *tenun \\
\hline to weave & *tinequn & ${ }^{*}$ tinequn \\
\hline batten of the loom & *baRija & *balija \\
\hline part of loom & *qatip-an & *qatip \\
\hline weaving spindle & ${ }^{*} \mathrm{qaNi}$ & ${ }^{*}$ qani \\
\hline woven skirt & *tapis & *tapis \\
\hline beads & *Sinuq & *hinuq \\
\hline waistband, belt & *bakes & *bakes \\
\hline \multicolumn{3}{|l|}{ wrap-around cloth } \\
\hline worn by women & *Seban & *heban \\
\hline head cover & & *tudun \\
\hline to sew & *taqiS & ${ }^{*}$ taqih \\
\hline
\end{tabular}

2. POc terms continued from PMP

\begin{tabular}{lllll} 
& PMP & POc & PCP & PPn \\
\hline to sew & ${ }^{*}$ zaqit & ${ }^{*}$ saqi(t) & & \\
to plait, woven, braided & ${ }^{*}$ añ $(\mathrm{a}, \mathrm{e}) \mathrm{m}$ & ${ }^{*}$ aña(m) & & \\
to plait/ weave (mats, baskets) & ${ }^{*}$ batuR & ${ }^{*}$ patuR-i & ${ }^{*} \mathrm{vatu}^{2}$ & fatu $^{2}$ \\
comb & ${ }^{*}$ saRu & ${ }^{*}$ saRu & ${ }^{*}$ seru & ${ }^{*}$ selu \\
trochus armband & ${ }^{*}$ lalak & ${ }^{*}$ lalak & & \\
barkcloth mallet & ${ }^{*}$ ikay ${ }^{1}$ & *ike & & \\
\hline
\end{tabular}

\section{POc terms without known antecedents in PAn/PMP}

\begin{tabular}{llll} 
& POc & PCP & PPn \\
\hline pearlshell ornament & *japi & ${ }^{*}$ jiva & ${ }^{*}$ tifa \\
shell disk used as ear-ring & ${ }^{*}\left(\right.$ sabi-)sabi ${ }^{4}$ & & \\
barkcloth garment & ${ }^{*}$ malo & ${ }^{*}$ malo & ${ }^{*}$ malo \\
man's clothing, esp. loincloth & ${ }^{*}$ tipi & & \\
to weave, plait s.th. & ${ }^{*}$ paus-i & \\
to weave & ${ }^{*}$ pai & \\
to (?finish off) plaiting a mat & ${ }^{*}$ tiki & \\
woman's grass skirt ${ }^{3}$ & ${ }^{*}$ nai & \\
oil or paint the body & ${ }^{*}$ pani & ${ }^{*}(\mathrm{p}, \mathrm{v})$ ani \\
decorate & ${ }^{*}$ nono ${ }^{5}$ & \\
herringbone pattern & ${ }^{*}$ mwati & \\
plaited cane armlet & ${ }^{*}$ bara & \\
\hline
\end{tabular}

Note: 1. A single non-Oceanic cognate in a MP language has been noted. 2. More generally, also to assemble, construct. 3. Reflexes only in Admiralties and North New Guinea, so possibly borrowed into one or the other group. 4. Possibly not distinct from *japi. 5. Weakly supported. 


\section{Kinship}

A fairly extensive set of kinship terms has been reconstructed for POc (Blust 1980b; Chowning 1991; Marck in prep. a; Milke 1958), including distinct sets of terms of reference and address. Table 11 shows only terms of reference for the relevant proto-languages. About half of the POc reference terms continue PMP etyma, including those for 'grandparent', 'father', 'mother', 'mother's brother', 'younger sibling of same sex', 'grandchild', 'spouse', 'parent-in-law' and 'sibling-in-law'. The presence of terms for siblings of opposite sex implies the existence of descent groups (Blust 1980b, 1994; Hage 1998, 1999a,b).

Table 12: Kinship terms of reference

\begin{tabular}{|c|c|c|c|c|c|}
\hline & PAn & PMP & $\mathrm{POc}$ & PCP & PPn \\
\hline \multicolumn{6}{|l|}{ A. Consanguineous kin } \\
\hline \multicolumn{6}{|l|}{ 1. $2^{\text {nd }}$ generation up } \\
\hline grandparent, ancestor & *apu & *apu & & & \\
\hline grandparent, ancestor & & ${ }^{*}$ t-impu & ${ }^{*}$ tubu & ${ }^{*}$ tubu & ${ }^{*}$ tupu-na ${ }^{1}$ \\
\hline \multicolumn{6}{|l|}{ 2. $1^{\text {st }}$ generation up } \\
\hline father, FaBro & *ama & *t-ama & *tama & *tama & *tama-na \\
\hline mother, mosis & *ina & ${ }^{*}$ t-ina & *tina & *tina & *tina-na \\
\hline mother's brother & ${ }^{*} \mathrm{ma}(\mathrm{n}) \mathrm{tuqaS}$ & ${ }^{*}$ ma(n)tuqa & *matuqa & & \\
\hline father's sister & & & ${ }^{*}$ aya $^{2}$ & & *mahakitanga \\
\hline \multicolumn{6}{|l|}{ 3. Ego's generation } \\
\hline older sibling same sex & & *tata & & & \\
\hline older sibling same sex & & & *tuaka & *tuaka & *tuaka-na \\
\hline younger sibling same sex & & *ta-huaji & ${ }^{*}$ tasi & *taði & *tahi-na \\
\hline brother (w. speaking) & & & ${ }^{*}$ mwaqane ${ }^{3}$ & ${ }^{*}$ mwaqane & *tua-naqane \\
\hline sister (m. speaking) & & & *papine & & *tua-fafine \\
\hline sister (m. speaking) & & *betaw & & & \\
\hline \multicolumn{6}{|l|}{ 4. $1^{\text {st }}$ generation down } \\
\hline child & *aNak & *anak & & & \\
\hline child, Bro ch, sis ch. & & & ${ }^{*}$ natu & & \\
\hline sister's child (man speaking) & & & *qalawa & & \\
\hline sister's son/daughter's husband & & *(d,D)awa & ${ }^{*}$ rawa ${ }^{4}$ & & \\
\hline \multicolumn{6}{|l|}{ 5. $2^{\text {nd }}$ generation down } \\
\hline grandchild & *umpu & ${ }^{*} \mathrm{t}-\mathrm{umbu}$ & ${ }^{*}$ tubu & & \\
\hline grandchild & & & ${ }^{*}$ makubu & ${ }^{*}$ makubu & ${ }^{*}$ makupu-na \\
\hline \multicolumn{6}{|l|}{ B. Affinal kin } \\
\hline \multicolumn{6}{|l|}{ 1. $1^{\text {st }}$ generation up } \\
\hline parent-in-law & & & *punao- & ${ }^{*}$ vunao & ${ }^{*}$ funao-na \\
\hline \multicolumn{6}{|l|}{ 2. Ego's generation } \\
\hline spouse & & *qasawa & *qasawa & *?aðawa & *2ahawa-na \\
\hline $\begin{array}{l}\text { sibling-in-law, wife's brother, possibly also } \\
\text { husband's father }\end{array}$ & & *hipaR & *qipaR & *?iva & \\
\hline
\end{tabular}

Note: 1. Many PPn kin terms contain a petrified suffix *-na, which reflects PCP -*ña ' 3 rd person singular possessor, his/ her'. 2. Blust (1980b) reconstructs *aya. Others have suggested the evidence as insufficient but Marck (in prep., a) gives reflexes from five different high-order subgroups. 3. Blust reconstructs *maRuaqane. There is support for both forms but *mwaqane is more widely reflected within Oceanic. 4. Blust (1980b:213) appears to favour 'affine not of Ego's generation, parent-in-law, child-in-law' as a gloss for POc *rawa. 


\section{Leadership and other social categories}

A number of terms for social categories (other than kin) are attributable to POc. Only a few of these are known to come from PAn and / or PMP etyma. There has been some debate over whether POc society had descent groups and hereditary chieftainship. Hage $(1998,1999 a)$ and Marck (in prep., b) propose, on a variety of grounds, that POc society had unilineal, probably matrilineal descent groups, and unilocal, underpinned by matrilocal or matri-avunculocal residence rules. Green (1994, 2002:25-6) proposes that the POc reflex of PMP term *Rumaq 'house' was also used to designate a descent group of some sort, as it is in any societies of eastern Indonesia but there is little support for this second sense among Oceanic witnesses.

Pawley (1982) proposed a pair of POc reconstructions *qalap(s) 'hereditary leader of a lineage, chief' and *qadiki 'son or heir of chief'. He also proposed two further reconstructions: POc *tau mwala, 'commoner, person of low rank' and (to an early Oceanic stage, ancestral to Micronesian and Polynesian) *kainana 'lineage, higher descent group'. Lichtenberk (1986) revised the form of the first reconstruction to *ta-la(m)pat (a compound of *ta- 'man', *la(m)pat 'big, great') and argued that its meaning is indeterminate between 'chief' and 'bigman'. He also proposed that the reconstructed meaning of *tau mwala is indeterminate between 'commoner' and 'worthless person'. Hage (1999a,b) and Blust (1995c) give other reasons for thinking that POc society had hereditary rank. Archaeologists point to features of Lapita pottery, especially the highly decorated vessels with stands, which suggest differential rank in Lapita society. Lichtenberk (1986) also revised the gloss for POc *adiki to 'eldest child' (we now write this form as *ariki), and argued that it was preceded by the personal article ${ }^{*}$ qa to mark it as a kin term.

Table 13: Terms for social categories

1. POc terms continued from PMP

\begin{tabular}{|c|c|c|c|c|c|}
\hline & PAn & PMP & POc & PCP & PPn \\
\hline spirit of the dead & ${ }^{*}$ qaNiCu & *qanitu & *qanitu & *?anitu & *?aitu \\
\hline powerful spirit & & ${ }^{*}(\mathrm{qa})$ tuan & *qatua(n) & *?atua & *?atua \\
\hline human being, person & ${ }^{*} \mathrm{Cau}$ & $*^{*}$ tau & *tau & ${ }^{*} \operatorname{tau}^{1}$ & ${ }^{*} \operatorname{tau}^{1}$ \\
\hline outsiders, aliens & ${ }^{*} \mathrm{qa}(\mathrm{R})(\mathrm{CtT}) \mathrm{a}$ & ${ }^{*} \mathrm{qa}(\mathrm{R}) \mathrm{ata}$ & ${ }^{*}$ qata $^{2}$ & & \\
\hline woman & *binaHi & *ba-binay & *papine & *vavine & ${ }^{*}$ fafine \\
\hline person of marriageable age & & ${ }^{*}$ paqoRu & *(tau-)paqoRu & *taupo?ou & ${ }^{*}$ taupoiou \\
\hline
\end{tabular}

2. POc terms without known antecedents in PMP

lineage, descent group (?)

leader, prob. hereditary chief

first-born child

person of low status

mariner, fisherman/ sailor

canoe owner/captain

person of the place

stranger, foreigner

human being (living)

dead person, ghost

man, male

$\underline{\text { girl }}$

\begin{tabular}{|c|c|c|}
\hline POc & PCP & PPn \\
\hline${ }^{*}$ kainana $^{3}$ & ${ }^{*}$ kainaya & ${ }^{*}$ kainana \\
\hline \multicolumn{3}{|l|}{${ }^{*}$ ta-la(m)pat ${ }^{4}$} \\
\hline *qa-ariki & *2ariki & *?ariki \\
\hline \multicolumn{3}{|l|}{ *(tau)-mwala } \\
\hline *tau-tasi & *tau-taði & ${ }^{*}$ tau-tai \\
\hline *tau-ni-waga & ${ }^{*}$ tau ni waga ${ }^{5}$ & ${ }^{*}$ tau-waka \\
\hline${ }^{*}$ kai + Place & ${ }^{*}$ kai [+ Place] & \\
\hline *tau-kese & *tau-keðe & *tau-kehe \\
\hline *tamwata & *taywata & *tanata \\
\hline \multicolumn{3}{|l|}{ *tau-mate } \\
\hline *(ta)mwaqane & *taywaqane & *taqane \\
\hline *keni & & \\
\hline
\end{tabular}

Note: 1. POc *tau 'person' is reflected only in compound nouns in PPn (often in the shortened form *ta-). This was probably the case in PCP, too. 2. In POc the meaning may have been 'people, person' (Blust 1972b). 3. Reflexes only in Micronesian and Polynesian, so attribution to POc is questionable. 4. Literally *ta- 'person', *la(m)pat 'great'. 5. Reflected in PPn (as *tau-waka) but lost in Fijian. But unlike PPn, PCP compounds of this type generally contained the genitive linker *ni. 


\section{Summary}

Almost all historical linguists would agree with the view, advocated in numerous works by Peter Bellwood, that the rapid spread of a language family strongly indicates migration of segments of the parent speech community. The initial dispersal of the Malayo-Polynesian languages appears to be a classic case of this type of rapid spread. In the space of 1000 years, between about 4000 and $3000 \mathrm{BP}$, people speaking the descendants of a single ancestral language-culture system spread from the Philippines into the Indo-Malaysian archipelago and Northwest Melanesia and then on into Remote Oceania. We can only date this sequence of movements by correlating it with archaeological events. Such a large demographic and cultural event should have left archaeological footprints and clearly this is so.

Lexical reconstructions greatly extend the archaeological record for the Austronesian-linked Neolithic cultures of the Philippines c. 4000-3600 BP (equated with PMP), the Bismarck Archipelago c. 3300-3100 BP (POc), Fiji ca $3000 \mathrm{BP}$ (PCP) and the Tonga-Samoa region c. 2000-1500 BP (PPn). The extensions apply particularly to non-material culture but also to material culture. For example, the outrigger canoe complex is missing from the relevant archaeological records, as is most of the house complex and almost all traces of the fishing net complex but these are all well attested in the linguistic record.

It can be seen that in most of the 11 lexical fields considered here there is very considerable continuity between PMP and POc, strongly supporting the conclusion that the Early Lapita cultural complex in large part continues a Southeast Asian tradition, and that there is considerable continuity in PCP and PPn. Many elements of this tradition were continued in PCP and PPn society. The powerful linguistic evidence for an Austronesian dispersal of the outrigger canoe complex, fishing techniques, house types and settlement patterns, agriculture and so on, does not preclude the possibility that some of the same cultural elements already existed in northwest Melanesia in pre-Lapita times. All it shows is that Austronesian speakers already had these elements when they entered northwest Melanesia.

What of those artefacts in the archaeological record considered to be indeterminate between "intrusion" and "integration", i.e. between an Austronesian-linked Southeast Asian origin and a pre-Austronesian origin in Near Oceania? Recall that Spriggs' list for this indeterminate category includes oval/lenticular polished adzes, grindstones, hinge-region Tridacna adzes, pierced shell pendants, shell beads, Trochus armbands, onepiece fishhooks, bone points or awls, vegetation clearance by fire, shellfishing and reef fishing, earth ovens and most of the Oceanic domesticated crop complex.

There is continuity in the general terms for axe/adze and handle but these give no indication as to the material or shape of the axe/adze itself or manner of hafting. The absence of a PMP term for stone oven or earth oven suggests that this method of cooking may have been borrowed by Austronesian speakers when they entered the Moluccas or Melanesia. There is continuity between PMP and POc in terms for angling (words for fishhook, line, and trolling lure) and in the term for the Trochus shell and armbands made from this.

PMP terms for the root crop complex and for some of the tree crops persist in POc, along with a number of words for agricultural practices. The fact that POc speakers carried their tradition of root and tree crop cultivation with them with them does not preclude the possibility that some of the plants were first domesticated in the New Guinea area, and that they moved westwards into Island Southeast Asia in the millennia before the Austronesian dispersal. A number of domesticated plants of New Guinea origin are candidates for this status (Kennedy 2007; Kennedy and Clarke 2004; Yen 1991). However, that is another story, separate from the question of the immediate origins of the Lapita culture. 


\section{0n interaction between Austronesian and non-Austronesian communities in the early Lapita period}

Finally, let us turn to the third question: Can linguistics say anything about the interaction between speakers of Austronesian and non-Austronesian languages in the early Lapita period? Some bold speculations recently put forward by Spriggs can serve as a point of departure:

My current view is that ... Lapita represents a new ethnic identity in the western Pacific, forged around a new prestige language (now labelled Proto-Oceanic Austronesian), which was spoken by people of originally disparate geographical and genetic origins. The new language was used to encode powerful origin myths to unite this disparate population, and Lapita pottery designs had an originally important role in the ritual performance of this group's identity ... This new iconography in the material culture, often representing an anthropomorphic face - perhaps the putative ancestor figure? - was an important mobilising and legitimating force as the Lapita culture was spread from the Bismarcks out into the Pacific ... (Spriggs 2003:205)

I read Spriggs as implying, in the first part of this passage, that while the Proto Oceanic language and its original speakers were intruders to the Bismarcks this language was soon learnt by diverse communities in the Bismarck Archipelago who were originally speakers of non-Austronesian languages and who were biologically distinct from the immigrant Austronesians. Learning the Lapita language was essential for these outsiders to gain entry into Lapita society. A further implication is that these originally non-Austronesian speaking communities also adopted much of the immigrants' material culture and social organisation while also retaining elements of their own.

What evidence can be found to test these speculations? I will leave aside the matter of biology and concentrate on language. On the linguistic front we have to look for evidence that might distinguish between acquisition of POc by communities of second language speakers and continuous transmission by successive generations of native speakers. ${ }^{5}$ Unfortunately, it is virtually impossible to find direct evidence of specific lexical borrowings from non-Austronesian languages into Oceanic that may have occurred in the Bismarcks some 3000 years ago - for one thing, the donor languages are unlikely to have left descendants. However, statistical evidence of borrowing may be sought by examining the number and nature of replacements in the lexicon of POc itself, compared with earlier stages, or in that of the immediate descendants of POc, namely proto-languages ancestral to high order subgroups of Oceanic, compared to POc.

Blust (1993) reconstructed PMP, PCEMP, PCMP and POc forms for the Swadesh 200 item basic vocabulary list and calculated the number of retentions and losses in each of the daughter proto-languages below PMP, with results as shown in Table 14.

Table 14: Percentages of PMP basic vocabulary (Swadesh 200 word list) retained in PCEMP, PCMP and POC

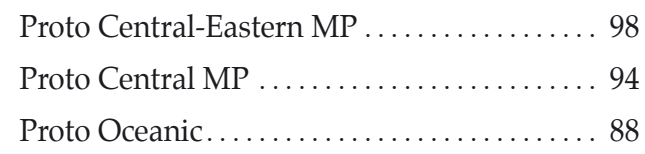

POc replaced $12 \%$ of PMP items on the PMP list. If we assume a 600 year gap between PMP and POc (a rough estimate based on the archaeological dates for the arrival of an Austronesian-associated Neolithic in the northern Philippines and Bismarcks, respectively) this gives a replacement rate of 2 percent per century, or 20 percent per millennium, which is almost exactly the mean rate of loss recorded for the sample of IndoEuropean languages used by Swadesh in his pioneering studies of rates of lexical replacement in the 1950s. 
There is no evidence here that extensive borrowing from non-Austronesian sources took place in the line of descent leading from PMP to POc.

The next place to look for signs of major perturbations in basic lexicon is in the proto-languages of the better-documented high-order subgroups of Oceanic. If language contact in the Bismarcks in the immediate post-POc period led to many lexical replacements these should show up in reconstructions of the proto-languages.

A recent study (Pawley 2007) compares retention rates for a sample of basic vocabulary in two subgroups of Oceanic, Northwest Solomonic and Southeast Solomonic, that are believed to have had very different histories of contact. In the area occupied by the Northwest Solomonic subgroup (Buka-Bougainvillle, Choiseul, the New Georgia Group and Santa Isabel) some 10 non-Austronesian languages still survive in two locations; Bougainville and the New Georgia Group. Two more non-Austronesian languages are spoken on Savo and Russell, small islands close to Guadalcanal on the eastern margin of the Northwest Solomonic group and the western margin of Southeast Solomonic. These 12 or so languages fall into several apparently unrelated families and are thought to be the relics of a much larger number of non-Austronesian languages that occupied the region when Oceanic speakers arrived. By contrast, there is reason to think that the region occupied by Southeast Solomonic languages had very few occupants when Oceanic speakers arrived. No non-Austronesian languages survive there (although two are spoken immediately to the west, on Savo and Russell).

The baseline in this study consisted of reconstructions of the 60 POc words with the highest high retention rates. A retention rate for each word was established by comparing basic vocabulary in 40 different contemporary Oceanic languages. Some 3000 years after the breakup of POc the more conservative Oceanic languages, such as those of Fiji and Polynesia, generally retain around 80 percent of these 60 words without significant change of meaning.

The study found a very large difference between the two subgroups. All Northwest Solomonic languages in the sample have replaced many more of the POc words than any of the Southeast Solomonic languages. Among Southeast Solomonic languages the average percentage of retentions is 73 . The highest single percentage is 86 and the lowest is 65 . Within Northwest Solomonic the average percentage of retentions is 49 . The highest is 59 and the lowest is 40 . The explanation given for this striking and consistent difference was that Northwest Solomonic languages have borrowed heavily from non-Austronesian languages while Southeast Solomonic languages have not. There seems to be no other reasonable explanation.

When did the large scale replacements take place in Northwest Solomonic? It can be shown that the replacements take different forms in different branches of Northwest Solomonic. The proto-language of the Northwest Solomonic group was lexically quite conservative: it had replaced only about four of the 60 POc words, giving a retention rate of 93 percent. (The figure for Proto Southeast Solomonic is similar.) That it to say, most of the large scale lexical change in Northwest Solomonic languages occurred after Northwest Solomonic speakers had dispersed across the region and, presumably, after they had established stable contacts with nonAustronesian speech communities, leading to long-term bilingualism and language shift.

The same study found that Proto Central Pacific (ancestral to Fijian, Rotuman and Polynesian) retained all of the 60 POc lexical items and Proto Polynesian kept 55 of the 60. By this measure, PCP was a very conservative Oceanic language and PPn also very conservative, considering that it belongs to a time 1000 years or more after the breakup of POc. No precise figures are available for other high-order subgroups, such as Proto Admiralties, Proto Western Oceanic, Proto Meso-Melanesian, Proto North \& Central Vanuatu and Proto Micronesian but my impression is that all will be found to retain 55 or more of the 60 items.

I read the lexical evidence as indicating that when Oceanic speakers first moved into Remote Oceania at about 3200-3100 BP they spoke a language little changed from POc. This in turn suggests that in the first few generations after Oceanic speakers arrived in the Bismarck Archipelago contact with non-Austronesian speakers was seldom of the kind that led Oceanic speakers to borrow basic vocabulary or for non-Austronesian speech 
communities to shift to Oceanic languages. Events of that kind were to become commonplace in various parts of Northwest Melanesia but not until somewhat later (see various papers in Dutton and Tryon 1994 and also Bradshaw 1995, Pawley 2006, Ross 1996c for a consideration of social and linguistic mechanisms associated with large scale borrowing and language shift in Melanesia). These conclusions are not inconsistent with archaeologists' findings about the preferred site locations of Early Lapita sites in the Bismarcks and the maintenance of intensive contacts between dispersed Lapita communities for the first few generations. The DNA record indicates that outsiders who entered Lapita communities as spouses were chiefly males. This is consistent with POc society as being matrilocal, with children growing up speaking the language of their mother and mother's sisters (Marck in prep., a).

\section{Notes}

1. I am grateful to Roger Green, Jeff Marck, Malcolm Ross and Matthew Spriggs for helpful comments on drafts of this paper.

2. I draw on a considerable literature on Austronesian culture history viewed from the standpoint of lexical reconstructions and subgrouping and, in particular, on a masterly overview by Blust (1995c). Other relevant works include, for the early stages of Austronesian, Blust (1976, 1980a,b, 1985) and Zorc (1994) and some of the contributions to Pawley and Ross (1994), for Proto Oceanic, Chowning (1991), Green (1994), Pawley and Green (1973, 1984), Pawley and Ross (1995) and Ross et al. (1998, 2003, in prep.), for Proto Polynesian, Kirch and Green (2001) and Marck (2000), as well as more general inter-disciplinary syntheses by Bellwood (1978, 1997), Kirch (1997, 2000), Shutler and Marck (1975), Pawley (2002) and Spriggs (1997). See also the references in the section on Austronesian lexical reconstructions. However, none of these works explicitly examines the lexical evidence pertaining to questions (1)-(3).

3. For a fuller bibliography of comparative historical works on Oceanic see Lynch et al. (2002).

4. Of course the words reconstructed for each stage are not all retentions from earlier stages. In every language there is constant lexical change: over time some words are completely lost and others undergo shifts of meaning. For example, about 140 fish names have been reconstructed for POc (Ross et al. in prep.). Of these, 85 have reflexes in PCP and about 57 in PPn (Ross et al. in prep.). That is to say, according to these data, PCP lost about $40 \%$ of the fish names reconstructed for POc and PPn lost about $60 \%$. The interval between POc and PPn was probably on the order of 1500 years - plenty of time to accumulate many changes.

5. Spriggs (pers.comm.) suggests that, given that the Lapita language became a badge of membership in the new prestige society in the Bismarck Archipelago, non-Austronesian speakers had to acquire it 'properly', without lots of foreignisms, and that this would explain why we don't find traces of extensive borrowing in POc or its immediate descendants. Unfortunately this claim, which assumes nativelike transmission in all cases, is not falsifiable linguistically. Indirect evidence for it must be sought in the genetic makeup of populations of Oceanic speakers.

\section{References}

Allen, J. and C. Gosden (eds) 1991. Report of the Lapita Homeland Project. Canberra: Department of Prehistory, Research School of Pacific Studies, The Australian National University. Occasional Papers in Prehistory 20.

Allen, J. and C. Gosden 1996. Spheres of Interaction and Integration: Modeling the Culture History of the Bismarck Archipelago. In J. Davidson, F. Leach, G. Irwin, A. Pawley and D. Brown (eds), Oceanic Culture History: Essays in Honour of Roger Green, pp. 183-197. Wellington: New Zealand Journal of Archaeology Special Publication.

Allen, J. and P. White 1989. The Lapita Homeland: Some New Data and an Interpretation. Journal of the Polynesian Society 98(2):129-146. 
Bellwood, P. 1978. Man's Conquest of the Pacific. London: Collins.

Bellwood, P. 1995. Austronesian Prehistory in Southeast Asia: Homeland, Expansion and Transformation. In P. Bellwood, J. Fox and D. Tryon (eds), The Austronesians, pp. 96-111. Canberra: Department of Anthropology, Research School of Pacific Studies, The Australian National University.

Bellwood, P. 1997. The Prehistory of the Indo-Malaysian Archipelago. (2nd edition). Honolulu: University of Hawaii Press.

Bellwood, P. and E. Dizon 2005. The Batanes Archaeological Project and the "Out of Taiwan" Hypothesis for Austronesian Dispersal. Journal of Austronesian Studies 1(1):1-33.

Bender, B. 1971. Micronesian Languages. In T.E. Sebeok (ed.), Current Trends in Linguistics, pp. 426-465. Vol. 8. Oceania. The Hague: Mouton.

Bender, B. and J. Wang 1985. The Status of Proto-Micronesian. In A. Pawley and L. Carrington (eds), Austronesian Linguistics at the $15^{\text {th }}$ Pacific Science Congress, pp. 53-92. Canberra: Pacific Linguistics.

Bender, B., F. Jackson, J.C. Marck, K. Regh, H-M. Sohn, S. Trussel and J. Wang 2003. Proto-Micronesian Reconstructions - I. Oceanic Linguistics 42(1):1-110. Proto-Micronesian Reconstructions - II. Oceanic Linguistics 42(2):271-358.

Biggs, B. 1965. Direct and Indirect Inheritance in Rotuman. Lingua 15:383-415.

Biggs, B. and R. Clark 2006. POLLEX. Proto Polynesian Lexicon. Computer files. School of Languages and Linguistics, University of Auckland.

Blust, R. 1970. Proto-Austronesian Addenda. Working papers in Linguistics, University of Hawaii 3(1):1-107 and ProtoOceanic Addenda with Cognates in non-Oceanic Languages. Working Papers in Linguistics, University of Hawaii 4(1):1-43, 4(8):1-17.

Blust, R. 1972a. Proto-Oceanic Addenda with Cognates in Non-Oceanic Languages. Working Papers in Linguistics, University of Hawaii 1(10):27-62.

Blust, R. 1972b. A Note on PAN *qa(R)(CtT)a 'outsiders, alien people'. Oceanic Linguistics 11(2):166-171.

Blust, R. 1976. Austronesian Culture History: Some Linguistic Inferences and their Relation to the Archaeological Record. World Archaeology 8(1):19-43.

Blust, R. 1977. The Proto-Austronesian pronouns and Austronesian Subgrouping: A Preliminary Report. University of Hawaii Working Papers in Linguistics, 9.2:1-15.

Blust, R. 1978a. Eastern Malayo-Polynesian: A Subgrouping Argument. In S.A. Wurm and L. Carrington (eds), Second International Conference on Austronesian Linguistics: Proceedings, pp. 181-234. Canberra: Pacific Linguistics.

Blust, R. 1978b. The Proto-Oceanic Palatals. Auckland: Polynesian Society.

Blust, R. 1980a. Austronesian Etymologies - I. Oceanic Linguistics 19:1-181.

Blust, R. 1980b. Early Austronesian Social Organization. Current Anthropology 21(2):205-247.

Blust, R. 1981. Variation in Retention Rates among Austronesian Languages. Paper presented to Third International Conference on Austronesian Linguistics, Bali, August 1981.

Blust, R. 1982. The Linguistic Value of the Wallace Line. Bijd. Taal, Land, Volkenkund, 138(2-3):231-250.

Blust, R. 1983-84a. More on the Position of the Languages of Eastern Indonesia. Oceanic Linguistics, 22-23:1-28.

Blust, R. 1983-84b. Austronesian Etymologies - II. Oceanic Linguistics 22-23:29-149.

Blust, R. 1984. A Mussau Vocabulary, with Phonological Notes. In Papers in New Guinea Linguistics No. 23, pp. 159-

208. Canberra: Pacific Linguistics.

Blust, R. 1985. The Austronesian Homeland: a Linguistic Perspective. Asian Perspectives 26:45-67.

Blust, R. 1986. Austronesian Etymologies - III. Oceanic Linguistics 25:1-123.

Blust, R. 1989. Austronesian Etymologies - IV. Oceanic Linguistics 28:111-180.

Blust, R. 1991. The Greater Central Philippines hypothesis. Oceanic Linguistics, 30:73-129.

Blust, R. 1993. Central and Central Eastern Malayo-Polynesian. Oceanic Linguistics, 32.2:241-293. 
Blust, R. 1994. Austronesian Sibling Terms and Culture History. In A. Pawley and M. Ross (eds), Austronesian Terminologies: Continuity and Change, pp. 31-72. Canberra: Pacific Linguistics.

Blust, R. 1995a. Austronesian Comparative Dictionary. Computer files, Department of Linguistics, University of Hawaii.

Blust, R. 1995b. The Prehistory of the Austronesian-speaking Peoples. Journal of World Archaeology 9(4):453-510.

Blust, R. 1995c. The Position of the Formosan languages: Method and Theory in Austronesian Comparative Linguistics. In P. Li, C. Tsang, Y. Huang, D. Ho and C. Tseng (eds), Austronesian Studies Relating to Taiwan, pp. 585-650. Taipei: Academia Sinica.

Blust, R. 1996. The Linguistic Position of the Western Islands, Papua New Guinea. In J. Lynch and F. Pat (eds), Oceanic Studies: Proceedings of the First International Conference on Oceanic Linguistics, pp. 1-46. Canberra: Pacific Linguistics.

Blust, R. 1998. A Note on Higher-order Subgroups in Oceanic. Oceanic Linguistics 37(1):182-188.

Blust, R. 1999. Subgrouping, Circularity and Extinction: Some Issues in Austronesian Comparative Linguistics. In E. Zeitoun and P. J-K Li (eds), Selected Papers from the $8^{\text {th }}$ International Conference on Austronesian Linguistics, pp 31-94. Taipei: Academia Sinica.

Bradshaw, J. 1995. How and Why Do People Change Their Languages? Oceanic Linguistics 34(1):191-202.

Burley, D. and S.P. Connaughton 2007. First Lapita Settlement and its Chronology in Vava'u, Kingdom of Tonga. Radiocarbon 49(1):131-137.

Burley, D., W.R. Dickinson, A. Barton and R. Shutler Jr. 2001. Lapita on the Periphery: New Data on Old Problems in the Kingdom of Tonga. Archaeology in Oceania 36(2):89-104.

Cashmore, C. 1969. Some Proto-Eastern Oceanic Reconstructions with Reflexes in Southeast Solomon Islands Languages. Oceanic Linguistics 8(1):1-25.

Chowning, A. 1991. Proto Oceanic Culture: the Evidence from Melanesia. In R. Blust (ed.), Currents in Pacific Linguistics. Papers on Austronesian Languages in Honour of George W. Grace, pp. 43-75. Canberra: Pacific Linguistics.

Clark, R. 1979. Language. In J.D. Jennings (ed.), The Prehistory of Polynesia, pp. 249-270. Canberra: The Australian National University Press.

Clark, R. 1994. Evolution, Migration and Extinction of Oceanic Bird Names. In A. Pawley and M. Ross (eds), Austronesian Terminologies: Continuity and Change, pp. 73-86. Canberra: Pacific Linguistics.

Clark, R. 2007. Proto North and Central Vanuatu Reconstructions. Computer Files. Dept of Applied Language Studies and Linguistics, University of Auckland.

Dempwolff, O. 1934-38. Vergleichende Lautlehre des Austronesischen Wörtschaftzes: 1. Induktiver Aufbau einer indonesischen Ursprache (1934). 2. Deduktiver Anwendung des Urindonesichen auf austronesische Einzelsprachen (1937). 3. Austronesiches Wörterverzeichnis (1938). Zeitschrift für Eingeborenen-Sprachen supplements 15, 17, 19. Berlin: Dietrich Reimer.

Dutton, T.E. and D.T. Tryon (eds) 1994. Language Contact and Change in the Austronesian World. Berlin: Mouton de Gruyter.Berlin.

Dye, T. 1983. Fish and Fishing on Niuatoputapu. Oceania 53:241-271.

French-Wright, R. 1983. Proto Oceanic Horticultural Practices. Unpublished MA thesis, Department of Anthropology, University of Auckland.

Geraghty, P. 1983. The History of the Fijian Languages. Oceanic Linguistics Special Publication 19. Honolulu: University of Hawaii Press.

Geraghty, P. 1986. The Sound System of Proto-Central-Pacific. In P. Geraghty, L. Carrington and S.A. Wurm (eds), Focal II: Papers from the Fourth International Conference on Austronesian Linguistics, pp. 289-312. Canberra: Pacific Linguistics.

Geraghty, P. 1989. The Reconstruction of Southern Oceanic. In R. Harlow and R. Hooper (eds), VICAL 1: Oceanic Languages. Papers from the Fifth International Conference on Austronesian Linguistics, pp. 141-156. Auckland: Linguistic Society of New Zealand 
Geraghty, P. 1990. Proto Oceanic *R and its Reflexes. In J.H.C.S. Davidson (ed.), Essays in Honour of G.B. Milner, pp. 51-93. London: School of Oriental and African Studies/ University of Hawaii Press.

Geraghty, P. 1996. Problems with Proto Central Pacific. In J. Lynch and F. Pat (eds), Oceanic Studies: Proceedings of the First International Conference on Oceanic Linguistics, pp. 83-91. Canberra: Pacific Linguistics.

Golson, J. 1971. Lapita ware and its transformations. In R.C. Green and M. Kelly (eds), Studies in Oceanic Culture History, Vol. 2, pp. 67-76. Pacific Anthropological Records 12. Honolulu: Bernice P. Museum.

Grace, G.W. 1959. The Position of the Polynesian Languages within the Austronesian (Malayo-Polynesian) Language Family. Bloomington: International Journal of American Linguistics.

Green, R.C. 1979. Lapita. In J.D. Jennings (ed.), The Prehistory of Polynesia, pp. 7-60. Canberra: The Australian National University Press.

Green, R.C. 1991a. The Lapita Cultural Complex: Current Evidence and Proposed Models. In P. Bellwood (ed.), IndoPacific Prehistory Vol. 2, pp. 295-305. Canberra: Bulletin of the Indo-Pacific History Association.

Green, R.C. 1991b. Near and Remote Oceania - Disestablishing “Melanesia” in Culture History. In A. Pawley (ed.), Man and a Half: Essays in Pacific Anthropology and Enthnobiology in Honour of Ralph Bulmer, pp. 491-502. Auckland: The Polynesian Society.

Green, R.C. 1994. Archaeological Problems with the Use of Linguistic Evidence in the Reconstruction of Rank, Status and Social organization in Ancestral Polynesian Society. In A. Pawley and M. Ross (eds), Austronesian Terminologies: Continuity and Change, pp.171-184. Canberra: Pacific Linguistics.

Green, R.C. 1999. Integrating Historical Linguistics with Archaeology: Insights from Research in Remote Oceania. Bulletin of the Indo-Pacific Prehistory Association, 18:3-15.

Green, R. C. 2000. Lapita and the Cultural Model for Intrusion, Integration and Innovation. In A. Anderson and T. Murray (eds), Australian Archaeologist: Collected Papers in Honour of Jim Allen, pp. 372-392. Canberra: Coombs Academic Publishing.

Green, R.C. 2002. Rediscovering the Social Aspects of Ancestral Oceanic Societies through Archaeology, Linguistics, and Ethnology. In S. Bedford, C. Sand and D. Burley (eds), Fifty Years in the Field. Essays in Honour and Celebration of Richard Shutler Jr's Archaeological Career, pp. 21-36. Auckland: NZ Archaeological Association Monograph 25.

Green, R.C. 2003. The Lapita Horizon and Traditions: Signature for One Set of Oceanic Migrations. In C. Sand (ed.), Pacific Archaeology: Assessments and Prospects. Proceedings of the International Conference for the 50th Anniversary of the First Lapita Conference (July 1952), pp. 95-129. Nouméa: Les Cahiers de l'Archéologie en Nouvelle-Calédonie, Vol. 15.

Hage, P. 1998. Was Proto-Oceanic Society Matrilineal? Journal of the Polynesian Society 107(4):365-379.

Hage, P. 1999a. Linguistic Evidence for Primogeniture and Ranking in Proto-Oceanic Society. Oceanic Linguistics 38:366-375.

Hage, P. 1999b. Reconstructing Ancestral Oceanic Society. Asian Perspectives 38:200-228.

Haudricourt, A. 1971. New Caledonia and the Loyalty Islands. In T.E. Sebeok (ed.), Current Trends in Linguistics, pp. 359-96. Vol. 8. Oceania. The Hague: Mouton.

Hockett, C.F. 1976. The Reconstruction of Proto Central Pacific. Anthropological Linguistics 18:187-228.

Hudson, E. 1989. All Nggaun. Oceanic Terms for ‘Dog' In R. Harlow and R. Hooper (eds), VICAL 1: Oceanic Languages. Papers from the Fifth International Conference on Austronesian Linguistics, pp. 283-304. Auckland: Linguistic Society of New Zealand.

Irwin, G. 1981. How Lapita lost its pots: the question of continuity in the colonisation of Oceania. Journal of the Polynesian Society 90:481-494.

Irwin, G. 1992. The Prehistoric Exploration and Colonization of the Pacific. Cambridge: Cambridge University Press.

Jackson, F.H. 1983. The Internal and External Relationships of the Trukic Languages of Micronesia. PhD dissertation, Department of Linguistics, University of Hawaii. 
Jackson, F.H. 1986. On Determining the External Relationships of the Micronesian Languages. In P. Geraghty, L. Carrington and S.A. Wurm (eds), Focal II: Papers from the Fourth International Conference on Austronesian Linguistics, pp. 201-238. Canberra: Pacific Linguistics.

Kennedy, J. 2007. Pacific Bananas: Complex Origins, Multiple Dispersals? Asian Perspectives.

Kennedy, J. and W. Clarke 2004. Cultivated Landscapes of the Southwest Pacific. RMAP Working Paper No. 50. Canberra: Resource Management in Asia-Pacific, Research School of Pacific and Asian Studies, Australian National University.

Kirch, P.V. 1995. The Lapita Culture of Western Melanesia in the Context of Austronesian Origins and Dispersal. In

P. Li, C. Tsang, Y. Huang, D. Ho and C. Tseng (eds), Austronesian Studies Relating to Taiwan, pp. 255-294. Taipei: Academia Sinica.

Kirch, P.V. 1997. The Lapita Peoples: Ancestors of the Oceanic World. Oxford: Blackwell.

Kirch, P.V. 2000. On the Road of the Winds: an Archaeological History of the Pacific Islands before European Contact. Berkeley: University of California Press.

Kirch, P.V. and T. Dye 1979. Enthnoarchaeology and the development of Polynesian fishing strategies. Journal of the Polynesian Society 88:53-76.

Kirch, P.V. and R.C. Green 2001. Hawaiki, Ancestral Polynesia: an Essay in Historical Reconstruction. Cambridge: Cambridge University Press.

Levy, R. 1980. Languages of the Southeast Solomon and the reconstruction of proto-Oceanic. In P.B. Naylor (ed.) Austronesian Studies: Papers from the Second Eastern Conference on Austronesian Languages, pp. 213-222. Ann Arbor: University of Michigan Center for South and South-East Asian Studies.

Lichtenberk, F. 1986. Leadership in Proto Oceanic Society: Linguistic Evidence. Journal of the Polynesian Society 95(3):341-356.

Lichtenberk, F. and M. Osmond 1998. Food Preparation. In M. Ross, A. Pawley and M. Osmond (eds), The Lexicon of Proto Oceanic. Vol. 1. Material Culture, pp.143-172. Canberra: Pacific Linguistics.

Lynch, J. 1991. Pigs and Dogs in Island Melanesia. In A. Pawley (ed.), Man and a Half: Essays in Pacific Anthropology and Enthnobiology in Honour of Ralph Bulmer, pp. 421-432. Auckland: The Polynesian Society.

Lynch, J. 2001. The Linguistic History of Southern Vanuatu. Canberra: Pacific Linguistics.

Lynch, J., M. Ross and T. Crowley 2002. The Oceanic Languages. Richmond, Surrey: Curzon.

Marck, J.C. 2000. Topics in Polynesian Language and Culture History. Canberra: Pacific Linguistics.

Marck, J.C. in prep. a. Proto Oceanic kin terms. In M. Ross, A. Pawley and M. Osmond (eds), The Lexicon of Proto Oceanic. The Culture and Environment of Ancestral Oceanic Society: Vol. 5, People and Society. Canberra: Pacific Linguistics.

Marck, J.C. in prep. b. Proto Polynesian *kainanga 'Matrilineal Clan or Lineage; Populace'.

Milke, W. 1958. Ozeanische Verwandtschaftsnamen. Zeitschrift für Ethnologie 83:226-229.

Osmond, M. 1998a. Horticultural Practices. In M. Ross, A. Pawley and M. Osmond (eds), The Lexicon of Proto Oceanic. Vol. 1. Material Culture, pp. 115-142. Canberra: Pacific Linguistics.

Osmond, M. 1998b. Fishing and Hunting Implements. In M. Ross, M., A. Pawley and M. Osmond (eds), The Lexicon of Proto Oceanic. Vol. 1. Material Culture. pp. 201-232. Canberra: Pacific Linguistics.

Osmond, M. 2000. Proto Oceanic Insects: the Supernatural Association. In S.R. Fischer and W. Sperlich (eds), Leo Pasifika: Proceedings of the Fourth International Conference on Oceanic Linguistics, pp. 383-302. Auckland: Institute of Polynesian Languages and Literatures.

Osmond, M. in prep. Proto Oceanic Fish Names. In M. Ross, A. Pawley and M. Osmond (eds), The Lexicon of Proto Oceanic. The Culture and Environment of Ancestral Oceanic Society: Vol. 4 Animals. Canberra: Pacific Linguistics.

Osmond, M. and M. Ross 1998. Household Artefacts. In Ross, M., A. Pawley and M. Osmond (eds), The Lexicon of Proto Oceanic. Vol. 1. Material Culture, pp. 67-114. Canberra: Pacific Linguistics.

Ozanne-Rivierre, F. 1982. Langues de Hienghène et proto-oceanic: phonologie comparée. In A-G. Haudricourt and F. Ozanne-Rivierre (eds), Dictionnaire thématique des languages de la region de Hienghène (Nouvelle-Calédonie), pp. 9-61. Paris: SELAF. 
Ozanne-Rivierre, F. 1992. The Proto Oceanic Consonantal System and the Languages of New Caledonia. Oceanic Linguistics 31(2):191-207.

Ozanne-Rivierre, F. 1995. Structural Changes in the Languages of Northern New Caledonia. Oceanic Linguistics 34(1):44-72.

Ozanne-Rivierre, F. and J-C. Rivierre 1989. Nasalization/oralization: Nasal Vowel Development and Consonant Shifts in New Caledonian Languages. In R. Harlow and R. Hooper (eds), VICAL 1: Oceanic Languages. Papers from the Fifth International Conference on Austronesian Linguistics, pp. 413-432. Auckland: Linguistic Society of New Zealand

Pavlides, C. and C. Gosden 1994. 35000 Year-old Sites in the Rainforests of West New Britain, Papua New Guinea. Antiquity 68:604-610.

Pawley, A. 1972. On the Internal Relationships of Eastern Oceanic Languages. In R.C. Green and M. Kelly (eds), Studies in Oceanic Culture History, vol. 3, pp. 1-142. Pacific Anthropological Records No. 13. Honolulu: Bishop Museum.

Pawley, A. 1982. Rubbishman, Commoner, Big-man, Chief? Linguistic Evidence for Hereditary Leadership in ProtoOceanic Society. In J. Siikala (ed.), Oceanic Studies. Essays in Honour of Aarne A. Koskinen, pp. 33-52. Helsinki: The Finnish Anthropological Society.

Pawley, A. 1985. Proto-Oceanic Terms for 'Person': A Problem in Semantic Reconstruction. In V. Acson and R. Leed (eds), For Gordon Fairbanks, pp. 92-105. Honolulu: Oceanic Linguistics (Special Publication No. 20).

Pawley, A. 1996a. The Polynesian Subgroup as a Problem for Irwin's Continuous Settlement Hypothesis. In J. Davidson, F. Leach, G. Irwin, A. Pawley and D. Brown (eds), Oceanic Culture History: Essays in Honour of Roger Green, pp. pp. 387-410. Wellington: New Zealand Journal of Archaeology Special Publication.

Pawley, A. 1996b. On the Position of Rotuman. In B. Nothofer (ed.), Reconstruction, Classification, Description-Festschrift in Honor of Isidore Dyen, pp. 85-119. Hamburg: Abera-Verlag.

Pawley, A. 1996c. Proto Oceanic Terms for Reef and Shoreline Invertebrates. In J. Lynch and F. Pat (eds), Oceanic Studies: Proceedings of the First International Conference on Oceanic Linguistics, pp. 133-162. Canberra: Pacific Linguistics.

Pawley, A. 2002. The Austronesian Dispersal: Languages, Technologies, Peoples. In P. Bellwood and C. Renfrew (eds), Examining the Farming/Language Dispersals Hypothesis, pp. 251-273. Cambridge: McDonald Institute of Archaeological Research, Cambridge University.

Pawley, A. 2003. Locating Proto Oceanic. In M. Ross, A. Pawley and M. Osmond (eds), The Lexicon of Proto Oceanic, Vol. 2, pp.17-34. Canberra: Pacific Linguistics.

Pawley, A. 2005 The Meaning(s) of Proto Oceanic *panua. In C. Gross, H.D. Lyons and D.A. Counts (eds), A Polymath Anthropologist: Essays in Honour of Ann Chowning, pp. 133-145. Research in Anthropology and Linguistics Monograph 6. Auckland: Department of Anthropology, University of Auckland.

Pawley, A. 2006. Explaining the Aberrant Languages of Southeast Melanesia: 150 years of Debate. Journal of the Polynesian Society 115(3):215-258.

Pawley, A. 2007. Was There Early Lapita Settlement of the Solomon Islands? Bringing Linguistic Evidence to an Archaeological Debate. Paper presented at $7^{\text {th }}$ International Conference on Oceanic Linguistics, Nouméa, July 2-6 2007.

Pawley, A. in prep. Patterns of Stability and Change in Oceanic Fish Names. In M. Ross, A. Pawley and M. Osmond (eds), The Lexicon of Proto Oceanic. The Culture and Environment of Ancestral Oceanic Society: Vol. 4 Animals. Canberra: Pacific Linguistics.

Pawley, A. and R.C. Green 1973. Dating the Dispersal of the Oceanic Languages. Oceanic Linguistics 12:1-67.

Pawley, A. and R.C. Green 1984. The Proto-Oceanic Language Community. Journal of the Pacific History 19(3):161-184.

Pawley, A. and M. Pawley 1994. Early Austronesian Terms for Canoe Parts and Seafaring. In A. Pawley and M. Ross (eds), Austronesian Terminologies: Continuity and Change, pp. 329-361. Canberra: Pacific Linguistics. 
Pawley, A. and M. Ross 1995. The Prehistory of Oceanic Languages: a Current View. In P. Bellwood, J. Fox and D. Tryon (eds), The Austronesians, pp. 39-74. Canberra: Department of Anthropology, Research School of Pacific Studies, The Australian National University.

Rivierre, J-C. 1991. Loss of Final Consonants in the North of New Caledonia. In R. A. Blust (ed.), Papers on Austronesian Languages and Ethnolinguistics in Honor of George Grace, pp. 415-432. Canberra: Pacific Linguistics.

Ross, M. 1988. Proto Oceanic and the Austronesian Languages of Western Melanesia. Canberra: Pacific Linguistics.

Ross, M. 1992. The Sound System of Proto Austronesian: an Outsider's View of the Formosan Evidence. Oceanic Linguistics 31(1):23-64.

Ross, M. 1994. Central Papuan Culture History: Some Lexical Evidence. In A. Pawley and M. Ross (eds), Austronesian Terminologies: Continuity and Change, pp. 389-479. Canberra: Pacific Linguistics.

Ross, M. 1996a. Is Yapese Oceanic? In B. Nothofer (ed.), Reconstruction, Classification, Description-Festschrift in Honor of Isidore Dyen, pp. 121-166. Hamburg: Abera-Verlag.

Ross, M. 1996b. Reconstructing Food Plant Terms and Associated Terminologies in Proto Oceanic. In J. Lynch and F. Pat (eds), Oceanic Studies: Proceedings of the First International Conference on Oceanic Linguistics, pp. 163221. Canberra: Pacific Linguistics.

Ross, M. 1996c. Contact-induced Change and the Comparative Method. In M. Durie and M. Ross (eds), The Comparative Method Reviewed: Regularity and Irregularity in Language Change, pp. 180-217. New York: Oxford University Press.

Ross, M. 2005. The Batanic Languages in Relation to the Early History of the Malayo-Polynesian Family. Austronesian Studies 1(2):1-24.

Ross, M. in press. The integrity of the Austronesian language family: from Taiwan to Oceania. In A. Sanchez-Mazas, R. Blench, M. Ross, I. Peiros and M. Lin (eds), Past Human Migrations in East Asia: Matching Archaeology, Linguistics and Genetics. London: Routledge Curzon.

Ross, M. and A. Naess 2007. An Oceanic Origin for Aiwoo, a Language of the Reef Islands? Paper read at $7^{\text {th }}$ International Conference on Oceanic Linguistics, Nouméa, July 2007.

Ross, M., A. Pawley and M. Osmond (eds) 1998. The Lexicon of Proto Oceanic. Vol. 1. Material Culture. Canberra: Pacific Linguistics.

Ross, M., A. Pawley and M. Osmond (eds) 2003. The Lexicon of Proto Oceanic. The Culture and Environment of Ancestral Oceanic Society: Vol. 2 The Physical Environment. Canberra: Pacific Linguistics.

Ross, M., A. Pawley and M. Osmond (eds) in prep. The Lexicon of Proto Oceanic. The Culture and Environment of Ancestral Oceanic Society: Vol. 3 Plants; Vol. 4 Animals; Vol. 5 People and Society. Canberra: Pacific Linguistics.

Shutler, R. and J. Marck 1975. On the Dispersal of the Austronesian Horticulturalists. Archaeology and Physical Anthropology in Oceania 10:81-113.

Spriggs, M. 1996. What is Southeast Asian about Lapita? In T. Akazawa and E. Szathmary (eds), Prehistoric Mongoloid Dispersals, pp. 324-348. Oxford: Oxford University Press.

Spriggs, M. 1997. The Island Melanesians. Blackwell: Oxford.

Spriggs, M. 2003. Post-Lapita Evolutions in Island Melanesia. In C. Sand (ed.), Pacific Archaeology: Assessments and Prospects. Proceedings of the International Conference for the 50th Anniversary of the First Lapita Conference (July 1952), pp. 205-212. Les Cahiers de l'Archéologie en Nouvelle-Calédonie, Vol. 15. Nouméa: New Caledonia Museum.

Summerhayes, G. 2000a. Lapita Interaction. Terra Australis 15. Canberra: Archaeology and Natural History and the Centre for Archaeological Research, The Australian National University.

Summerhayes, G. 2000b. Recent Archaeological Investigations in the Bismarck Archipelago, Anir-New Ireland Province, Papua New Guinea. Indo-Pacific Prehistory Bulletin 19:167-174.

Summerhayes, G. 2001. Lapita in the Far West: Recent Developments. Archaeology in Oceania 36:53-63.

Tryon, D. 1994. Oceanic Plant Names. In A. Pawley and M. Ross (eds), Austronesian Terminologies: Continuity and Change, pp. 481-509. Canberra: Pacific Linguistics. 
Walter, R. 1989. Lapita Fishing Strategies: a Review of the Archaeological and Linguistic Evidence. Pacific Studies 13(1):127-149.

White, P., J. Allen and J. Specht 1988. Peopling the Pacific: the Lapita Homeland Project. Australian Natural History 22:410-416.

Yen, D.E. 1991. Domestication: the Lessons from New Guinea. In A. Pawley (ed.), Man and a Half: Essays in Pacific Anthropology and Enthnobiology in Honour of Ralph Bulmer, pp. 558-569. Auckland: The Polynesian Society.

Zorc, D. 1994. Austronesian Culture History through Reconstructed Vocabulary (an Overview). In A. Pawley and M. Ross (eds), Austronesian Terminologies: Continuity and Change, pp. 595-624. Canberra: Pacific Linguistics. 